\title{
The Impact of Terrorism on European Tourism
}

\author{
Shaen Corbet ${ }^{a *}$, John F. O'Connell ${ }^{b}$, Marina Efthymiou ${ }^{a}$, Cathal Guiomard ${ }^{a}$, Brian Lucey ${ }^{c, d, e}$ \\ ${ }^{a}$ DCU Business School, Dublin City University, Dublin 9, Ireland \\ ${ }^{b}$ Centre of Aviation Research, School of Hospitality and Tourism Management, University of Surrey, UK \\ ${ }^{c}$ Trinity Business School, Trinity College Dublin, Dublin 2, Ireland \\ ${ }^{d}$ University of Sydney Business School, University of Sydney, Sydney, New South Wales, Australia \\ ${ }^{e}$ Distinguished Research Fellow, Institute of Business Research, University of Economics Ho Chi Minh City, 59C \\ Nguyen Dinh Chieu, Ward 6, District 3, Ho Chi Minh City, Vietnam \\ *Corresponding Author: shaen.corbet@dcu.ie
}

\begin{abstract}
This paper estimates the influence of terrorist attacks on European tourism through the short-term post-hoc response of the airline industry and passengers. We use a seasonally-adjusted ARMAGARCH methodology on unique datasets that examine changes in tourism as measured by ASKs, seats filled and changes in both fares and revenues. Traffic flows are found to fall despite significant fare reductions; however, this response varies substantially based on the flight origin and tickettype purchased. We found that business travel slows substantially due to duty of care legislation for corporate transport. While we found evidence indicating substantial airline fare reductions, in the majority of investigated cases this response was unable to mitigate substantial reductions in passenger demand and flows across varying ticket types.
\end{abstract}

Keywords: Terrorism; European aviation industry; tourism flows; ARMA-GARCH.

\section{Introduction}

The tourism industry has been found to be inherently vulnerable to both natural and humancaused disasters (Khazai et al. [2017]), such as terrorist attacks that originate through sophisticated mechanisms or indeed indiscriminate attacks as witnessed in Europe in the past decade. The concept of terrorism is found to be relatively undefined (Silke [2003]), which often obstructs scholars from developing shared methods, approaches and benchmarks. Crenshaw [1981] defines terrorism as a particular form of political or social violence, including attacks on a small number of victims in order to influence a wider audience and effect political, religious or social change. All definitions agree that terrorism aims beyond the immediate victim(s) or object of attack. Nevertheless, none of the definitions incorporates the disruption to the destination and the thread to the tourism economy. 
We define terrorism in this paper as 'the creation of fear either by an act of violence or by threatening the destination with an act of violence, that causes disruption to the tourism flows, infrastructure and overall operations'. Terrorism usually discourages tourists from visiting affected destinations (Liu and Pratt [2017]). The aftermath of such an incident can be initially quite acute such as that experienced in the Brussels bombing in 2016, when the main airport was shut down for more than a week. This can generate very significant social and economic effects for the affected destinations. The image and reputation of the tourist destinations subjected to the terrorist incident are damaged and usually their restoration can be very difficult (Faulkner [2001]). According to a study conducted by Liu and Pratt [2017], nine countries out of ninety-five investigated faced a substantial long-run impact of terrorism on international tourism and twenty-five of ninety-five countries faced a short-run effects.

The literature based on the tripartite interlinkage of tourism, aviation and terrorism is sparse. Wolff and Larsen [2014] researched the effect of the 2011 Norway massacres on perceived risk among tourists and concluded that such perceptions did not change and the destination's image remained that of a safe destination when compared to its international peers. Saha and Yap [2014] found that political instability has more severe effects on tourism than a terrorist attack. However, there is also a broad acknowledgement by researchers such as Liu and Pratt [2017] and Araña and León [2008] that the impact of terrorism attacks on tourism demand, especially that of international tourism demand, is still not sufficiently researched.

Broad research based on the impact of terrorism on the aviation industry is also relatively sparse. Goodrich [2002] found that the airline load factor and hotel occupancy rates fell by approximately $50 \%$ after the $9 / 11$ attacks. Nevertheless, transport remains an essential element of the tourism industry that contributes to destination development (Efthymiou and Papatheodorou [2015]). In the aftermath of one of the most severe periods of financial crisis witnessed within Europe, tourism has taken even more of a central role in both the lives and economic welfare of European states, particularly those on the periphery (Corbet [2016]). Some of the regions that experienced the wave of terrorism studied in this paper, had prior experience of terrorism including the UK, Ireland and Spain. But since 2000, terrorist attacks have extended across a broader geographical area (See both Figure 1 for a geographical representation and Table 1 for the associated statistics and description of each European attack). Furthermore, the characteristics of recent attacks are, arguably, more pronounced and more acute than earlier phases of terrorism. Recent attacks have become frequent, more devastating due to the number of lives lost and persons injured, and use more sophisticated due to the use of basic everyday items that are far outside the scope of what we expect of our security forces to anticipate (for example, the use of passenger vehicles, kitchen knives and other frequently used items). Since 2008, against a background of economic dislocation, increased welfare inequality and numerous immigration controversies, these attacks have not only elevated public fears but have contributed to increased social tensions and a more populist style of politics (Corbet 
et al. [2018]; Corbet and Larkin [2018]), while directly damaging many economic sectors including transportation and tourism.

Our research is positioned to advance understanding of terrorism and its influence on tourism in a European context, which is particularly relevant given the extension of terrorist attacks to additional cities and regions that would previously have been relatively unaffected. The importance of such research is further underlined for regions reliant on both aviation and tourism for economic development and prosperity. We develop on the important work of Chen and Siems [2004]; Drakos [2004], Eldor and Melnick [2004], Gillen and Lall [2003] and Hall [2010]. Our paper aspires to specifically develop the literature that has focused on the influence of terrorism at a local level such as research based on Nepal by Bhattarai et al. [2005], the effects with regards to influences based on political instability (Sönmez [1998]), and the perceptions of risk due to events (such as major sporting events such as the Olympics as investigated by Walters et al. [2017]).

Our research attempts to establish the scale of disruption to the tourism sector through aviation flows in the period immediately following a European terrorist attack. We do so by utilising two datasets that measure first, the number of seats supplied to and from the destination city under observation; and second, the passenger demand together with the revenues generated and the associated fares charged by the airlines that provide the transport service. Through the use of multiple years of data, we are able to generate seasonally-adjusted results that present substantial robustness to both our selected methodologies and the results that they yield.

The remainder of the paper is organised as follows. Section 2 investigates a variety of previous research associated variously with the topics of terrorism, air travel and tourism as well as their broad interrelationships. Section 3 provides a thorough explanation of the types of data that were used in the analysis and the stylised facts and trends contained within. Section 4 provides a detailed explanation of the selected methodologies. Section 5 outlines the results while Section 6 concludes the paper.

\section{Contextual setting}

\subsection{Terrorism}

Terrorism aims to create a widespread intimidation or fear (Jongman [2017]) and it exists in many differing forms. Hoffman [2006] described the effects of ethno-nationalist, separatist, international, religious and state-sponsored terrorism. Such attacks often develop from the belief that an ultimate power has sanctioned and commanded the terrorist violence for the greater glory of their faith (Martin [2017]). The Islamic State (IS), listed as a terrorist group by both the United Nations and the European Union, has conducted acts of religious terrorism. IS claims religious, political and military authority over all Muslims worldwide (Cockburn [2015]). In contrast, politically-motivated organisations like Hamas or the Provisional IRA defined themselves as freedom fighters. However, 
the central causes of terrorist violence remain unclear. Collective rationality, disaffection within an elite, logical choice and political strategy, as well as lack of opportunity for political participation and codes of self-sacrifice, may all explain terrorism (Martin [2017]). Extremism is a fundamental component of terrorism. This deeply held belief of autonomy is an extremist system characterised mainly by intolerance, moral absolutes and conspiratorial beliefs (Martin [2017]). Mujahideen, which means struggle as in 'holy war', is essentially a military force of Muslim guerilla fighters that believe in a fundamentalist interpretation of Islam (Cockburn [2015]).

However, terrorist attacks are not random and such terrorist violence can be opportunistic when targets appear (Marsden and Schmid [2011]). Such attacks have created social disruption demonstrating a governments' apparent weakness, while the terrorist group is further publicised on a global platform, creating disruption and chaos. For example, Islamic State has been identified as a strongly media-orientated terrorist organisation (Gates and Podder [2015]), where targets are selected for symbolic reasons and propaganda is used for audience manipulation, which often leads to the contagion effect (Glazzard [2015]). By kidnapping, bombing and killing, Islamic State aims to impose their demands and assure their members that their international power remains intact and to further attract potential supporters (Rehman [2005]). Analysing previous terrorist attacks such as those including the attack on the satirical newspaper Charlie Hebdo in Paris; a further series of coordinated terrorist attacks in Paris; coordinated suicide bombings at Brussels Airport and at a metro station; and the devastating truck-attack that was deliberately driven into crowds in Nice, IS utilises all available options (Corbet et al. [2018]). Further, IT does not appear to have a 'signature method of attack' anymore. This makes it very difficult for security personnel throughout Europe to anticipate and respond.

\subsection{Terrorism's impact on Aviation and Tourism}

Leiper [1979] in his tourism-system methodology included transit routes as an essential element. Each industry with a tourism ratio (identified as tourism-related receipts as a percentage of its total turnover) exceeding $15 \%$ is regarded as part of the tourism system (Efthymiou and Papatheodorou [2015]). Therefore, commercial aviation and marine cruising, both with a ratio over $90 \%$, are regarded as par excellence tourism sectors (Page [2011]; Duval [2007]; Stabler et al. [2009]). Koo et al. [2017] suggest that consistent air services are essential for many tourism destinations and Bieger and Wittmer [2006] suggested that in well-developed travel markets, air transport is the main travel mode for overnight stays of more than four nights. Further, Mo et al. [1993] identified transportation as a factor in the creation of a 'destination product'. For instance, charter airlines generated increases popularity in the European Mediterranean (Efthymiou and Papatheodorou [2018]). Aviation's contribution to tourism development has been investigated by a number of researchers. Prideaux [2000] researched the role of the transportation system in destination development; Du- 
val [2013] analysed the implication of international air transport for tourist flows and Khadaroo and Seetanah [2008] focused on the role of transport infrastructure. Further, Page [2005] analysed the tourist transportation system; whereas Papatheodorou [2002] elaborated on the relationship of tourism and air transport. Forsyth [2006] examined the effect of air liberalisation on the Australian tourism sector and Dobruszkes et al. [2016] assessed the impact of airline liberalisation on Morocco and Tunisia tourism development.

Sönmez et al. [1999] stated that terrorists target tourists to achieve their ideological objectives, to gain publicity and because the tourism environment provides them with camouflage. Fleischer and Buccola [2002] suggested that tourist demand will decrease substantially for two months after a terrorist attacks while Pizam and Fleischer [2002] suggest that a destination will necessitate six to twelve months to recover, on the condition that such terrorist events are not repeated while Khazai et al. [2017] argue that media exaggeration lead to a slower recovery of the affected destination. Araña and León [2008] propose that when an affected destination is very similar (a close substitute) to a non-affected destination, the impact of the terrorist attack in the tourist's behaviour is high. Moreover, culture, personal experience and the cost of avoiding the risk define the level of impact of terrorism on tourist behaviour (Yechiam et al. [2005]). Their research does not distinguish between the reasons for travelling, such as whether the trip is designated as business tourism and visiting friends and relatives travel (also known as VFR travel).

Bassil [2014] researched the effects of domestic and international terrorism on tourism demand to Lebanon, Turkey and Israel over the period 1995 through 2007. He found that the impact on tourism is related to the magnitude of terrorist attacks (designated as low, medium and high). The paper finds that tourism demand is significantly affected in these countries by attacks that take place domestically relative to the investigated country as well as neighbouring territories. Hamadeh and Bassil [2017] analysed the impact on tourist arrivals in the Lebanon attributable to terrorism while considering the impact of the Syrian civil war, in the period between January 1995 and December 2014. The results reveal a significant negative marginal effect for terrorism on tourism demand. Neumayer and Plümper [2016] analyse the effects of attacks executed in Islamic countries on citizens from Western countries. These attacks are found to generate falls in tourism flows from many Western states to many Islamic destinations, not simply from the countries where the victims originated or to the countries where the attacks took place. The impact of terrorist events on tourism may also be heavily affected by government policy in the countries where tourists originate. For example, following a 2015 terrorist attack in which many of its citizens died, the UK government advised its citizens not to travel to Algeria. Many other countries foreign ministry websites also discourage their citizens from travelling to certain countries from time to time. US tourists have been advised not to travel to Turkey among other places. However, except for Turkey, the destinations studied in this paper have not been the subject of governmental travel bans so for the most part this topic is beyond the scope of this paper. 
Fox [2014] states that research into the direct correlations between airline safety and profitability has produced mixed results. Nevertheless, there is broad agreement that terrorism has had a tremendous effect on travel demand. One of the most significant terrorist attacks is that of the $9 / 11$ attacks on New York city in 2001. In the immediate aftermath, there was evidence of a sharp decline of both domestic and international passenger traffic. The entire U.S. civil aviation system closed for two days (Chen et al. [2017]) and airlines lost over $\$ 100$ million in sales revenue (Goodrich [2002]). Subsequently, airlines downsized their workforce due to their deteriorating financial performance. IATA [2011] reported that US airlines employed 444,700 workers in 2003, $14.6 \%$ less than in 2000. The domestic operating revenue also declined with passengers using alternative means of transportation for short-haul travel to avoid airport security queues. The airline industry further responded by cutting capacity, namely Available Seat Kilometres (ASKs), by $2.8 \%$ in 2001 and by an additional $3.9 \%$ in 2002 (IATA [2011]). Swissair and Sabena collapsed within months of the attack. It took three years to recover the $\$ 22$ billion of lost revenues (6\%) (IATA [2011]). This provides substantial evidence of the substantial decline in economic conditions at not only the corporate-level, but indeed the sovereign level in the aftermath of these acts of terror. We build upon the academic knowledge presented in this literature review, we aim to test the following research hypotheses:

- H1: Airlines responded to recent terrorist attacks in Europe by reducing their supply of seats to the destinations affected.

- H2: Passengers responded to recent terrorist attacks in Europe by reducing their demand for seats on flights to the destinations affected.

- H3: The response of passengers to the terrorist attacks differed according to whether the flight originated in the US or the EU.

- H4: The response of passengers to the terrorist attacks differed according to whether they had purchased a business or an economy ticket.

\section{Data}

Our data selection process takes three specific stages: 1) the choice of the terrorist events to investigate; 2 ) the use of international passenger flows to the cities and regions that have experienced the terrorist attacks; and 3) the revenues and average fares charged, sub-divided by class of travel for each of the investigated routes. We have included European terrorist attacks based on the breadth of international newspaper coverage of the incident. We have only included incidents where news reports used the specific word 'terror' and those that were covered on the front page of at least one of the major newspapers of each of the EU-28 countries (fewer countries where applicable) based on an analysis of the LexisNexis database on the day after the denoted attack. A concise 
list of our selected events are included in Table 1. Our analysis spans the period between 2011 and 2018. France experienced the most attacks (four attacks), and Paris was the city most frequently attacked (three separate times). From a direct terror attack, the largest number of fatalities had taken place in Paris in November 2015 (137 persons). In this case, the attack included three stages, with a suicide-bombing at a football match at Stade de France, a bombing incident, and lastly a mass shooting at a music concert at the Bataclan theatre. The largest number of injuries occurred in Manchester, United Kingdom in May 2017 (512 persons) where a suicide bomber detonated an improvised explosive device at a music concert with 14,200 people in attendance. Although not directly denoted as a terrorist attack, the Turkish coup d'etat that had taken place in July 2016 is also analysed in detail. It is estimated that more than 300 people died in this incident and over 2,100 people were injured. Figure 1 presents a geographical representation of the nations that have experienced a significant terrorist attack between 2011 and 2018.

\section{Insert Figure 1 and Table 1 about here}

The second stage of our analysis necessitated the use of data based on two measures: the number of airline seats supplied and the Available Seat Kilometres (ASKs). Data is obtained from OAG Analytics $^{1}$. OAG is a subscription database that houses the world's largest collection of air travel data, including the definitive schedules database of more than 980 airlines and over 4,000 airports. It handles more than 57 million records of flight status updates per year and its interactive platform allows users to extract and analyse seat capacity. Table 2 provides the average data value for each of our selected European terrorist attacks. There exist gaps due to the unavailability of data that distinguish business and economy seats; however, a full sample of ASK and aggregate seat sale data is provided. Routes are sub-divided by a flight's origin: EU or US. Within the sample, London is the busiest airport as measured by ASKs, with almost 412 million ASKs and 183,222 seats filled daily over the period. Turkey has the highest number of seats sold (325,363 seats). Based on our sample, London is the busiest airport network for business travellers.

\section{Insert Table 2 about here}

The final data that was applied in the analysis was both demand and financial orientated. Data was obtained through a Global Distribution System (GDS) called Sabre AirVision, Market Intelligence Data Tapes $\left(\mathrm{MIDT}^{2}\right)$, which is a subscription database that collects information pertaining

\footnotetext{
${ }^{1}$ Available at https://analytics.oag.com/analyser-client/home

${ }^{2}$ Available at https://emergo5.sabre.com/community/login?goto=https://emergo5.sabre.com/community/home
} 
to passenger demand, fares and revenues earned by airlines that can be customised to derive information for specific routes. The system amasses information on indirect bookings such as online travel agents, travel management companies and global travel retailers through a GDS. The main limitation of this database is that it does not capture direct bookings from on-line distribution channels such as airline websites. Nevertheless, the system delivers market booking information of user-defined markets along with the activity of all agency bookings in those markets. There were limitations for some data, which was unavailable prior to 2013; thus the 2011 attack in Frankfurt, Germany, while included in the estimates of the impact of attacks on traffic could not be included in later parts of the analysis that required the financial data.

In summary, the paper includes twelve terrorist attacks in its analysis; these occurred in ten cities (Paris had three attacks). Our traffic data is available for all the attacks (12) so our analysis of the impact of terrorism on traffic can be carried out for all attacks. Average fare data is available by city (10) and we report it below accordingly. Data distinguishing fares by ticket class are, however, available for only seven of the cities in our study. Therefore, our comparison of the impact of terrorism on business travel versus economy travel only includes seven cities.

\section{Insert Tables 3 about here}

Table 3 reports the average fares for the routes that we have examined, sub-divided by both the month and origin of the flight, either Europe or the United States. Each case is analysed specifically for the two years before, year of the incident and two years after the particular terrorist attack. The table included fares data represents all passenger airports located within the city under investigation (entire country in the case of the Turkish coup d'etat). Price data is represented in US (\$) dollars at the point in time that the observation was recorded. As one would expect, flights of United States origin costs substantially more than their European counterparts as displayed in Table 3. There is evidence of premium pricing in the summer, with Turkey being the most expensive route to reach from Europe and Nice being the most expensive route to reach from the United States.

\section{Methodology}

To understand the impact of major European terrorist attacks on air travel flows, we follow a two-stage process of investigation. In the first stage, we use a seasonality-adjusted regression methodology to investigate the immediate impact on air travel numbers of a terrorist incident in Europe. Our data, as explained in Section 3 enables the investigation of effects on ASKs and aggregate seats filled per arriving flight at the attacked city. This can also be sub-divided into economy and business class seats. In the second stage, as a robustness check of results based on passenger flows, we investigate the net effect of the terrorist attack on airline revenues. A significant 
deterioration of airline revenues in the period after each terrorist attack however, can be attributed to two separate factors: 1) tourists and business travellers alike have decided (at unchanged fares) not to travel to the destination under study; or 2) the airlines, to mitigate the tendency for passenger numbers to fall, have reduced fares leading to a reduction in revenues (even with unchanged traffic).

On the basis of the above information, we first set out to analyse the direct effects of terrorist attacks on airline passenger numbers. Our calculated changes in passenger numbers flows and ticket pricing are calculated as:

$$
y_{t}=\left(\ln N_{t}-\ln N_{t-1}\right)
$$

where $y_{t}$ is the change in the selected dependent variable on trading day $\mathrm{t}$, whether it is the change in passenger flows as measured by the number of seats purchased or the ASKs travelled. The selection of methodology is complicated by the presence of seasonality and the random nature of our selected terrorist attacks. The best methodology is that of a regression model with dummy variables indicative of the month. Deterministic seasonality $\left(S_{t}\right)$ can be written as a function of seasonal dummy variables, denoted as $M_{t}$, where $M_{1 t}$ is denoted by unity if $S_{t}$ is located in the first period or zero otherwise. At any one time period $t$, one of the seasonal dummy variables will equal unity and all others will equal zero. In our selected methodology, deterministic seasonality is best represented as a linear function of the dummy variables:

$$
S_{t}=\left\{\begin{array}{ccc}
y_{1} & \text { if } & t=\text { Jan } \\
y_{2} & \text { if } & t=\text { Feb } \\
\vdots & & \\
y_{12} & \text { if } & t=\text { Dec }
\end{array}\right\}=\sum_{i=1}^{s} \gamma_{i} M_{i t}
$$

Therefore, we estimate a baseline methodology that excludes one month (which is found to be February throughout our analysis) since regressing on both the intercept and all seasonal dummies are collinear and redundant. We are further focused on the initial response to airline passenger numbers in the thirty-day period directly after the terrorist attack. We therefore include a further dummy variable that specifically investigates this period $D_{30 t}$. Through a thorough analysis (results available on request from the authors), we found that thirty days was determined as best representative of the terrorist attack impact.

$$
y_{t}=\alpha_{0}+\sum_{i=1}^{s-1} \beta_{i} M_{i t}+D_{30 t}+e_{t}
$$

Equation (3) therefore presents a regression analysis that generates an estimate of the scale of impact due to the denoted terrorist attack while controlling our selected methodology for the presence of seasonality. Our first stage of analysis focuses on two points of interest. The first is 
based on the effects of the attacks on ASKs and the total number of seats that have been filled respectively. The second is based on the number of business class and economy seats that have been filled. Each of these methodologies are further sub-divided to investigate as to whether there are distinct differences between flights arriving from Europe and flights arriving from the United States. Therefore, the our selected methodologies take the form:

$$
\begin{gathered}
A S K_{t}=\alpha_{0}+\sum_{i=1}^{s-1} \beta_{i} M_{i t}+D_{30 t}+e_{t} \\
\text { Total }_{t}=\alpha_{0}+\sum_{i=1}^{s-1} \beta_{i} M_{i t}+D_{30 t}+e_{t} \\
\text { Business }_{t}=\alpha_{0}+\sum_{i=1}^{s-1} \beta_{i} M_{i t}+D_{30 t}+e_{t} \\
\text { Economy }_{t}=\alpha_{0}+\sum_{i=1}^{s-1} \beta_{i} M_{i t}+D_{30 t}+e_{t}
\end{gathered}
$$

where $A K S_{t}, T O T S_{t}, B U S C_{t}$ and $E C O N C_{t}$ represent ASKs, total seats, business class seats and economy seats respectively. The described methodologies use the same independent variables but differing dependent variables, therefore providing estimates of the calculated increase or decrease in the dependent variable when considering the described independent variables. The next stage of our analysis focuses on the response of the airline industry in the period after a terrorist attack on a European city. To undertake the analysis, we investigate the effects of the incident on revenues and fares of flights departing to the destination city that experienced the attack. Concerning fares, it would of course be preferable to possess fare information in real-time, but this data is not available to the public. We therefore utilise financial data, which enables the use of a standardised Generalised-ARCH methodology (GARCH). The structure of our selected $\operatorname{GARCH}(1,1)$ methodology is explained in detail in Appendix 1.

\section{Results}

Table 4 presents the results obtained by regressing the daily airline sets supplied (as measured by ASKs) on a set of monthly dummies and a further dummy representing a given terrorist incident over the thirty day period following the attack $\left(D_{30 t}\right)$. The coefficient on the $D_{30 t}$ variable indicates that, allowing for monthly patterns, that airlines reduced the seat capacity they offered in four of the locations (Paris, Copenhagen, Turkey and Brussels) out of a total of twelve studied. The largest decline was in Brussels (-12.3\%); this is not surprising, since the bombs completely closed 
the airport for nearly two weeks. Large declines in capacity are also observed in Copenhagen ($10.6 \%$ ) and reductions of $4 \%$ and $1 \%$ are seen in Paris (January 2015) and Turkey respectively. The other eight locations recorded a rise in ASKs thirty days following an attack, holding constant the impact of purely seasonal factors. Most of these increases ranged from $1 \%$ to $3 \%$, except for Manchester $(+6.8 \%)$ and in particular Berlin $(+10.5 \%)$.

\section{Insert Table 4 about here}

It might be considered that thirty days is not long enough for most airlines to modify the scale of their services (whether up or down) in response to shocks, particularly given that airlines normally set a schedule a full season in advance (summer or winter). Moreover, low-cost carriers, at least, are considered to follow a policy sometimes termed 'yield passive, load aggressive', which would imply the effects of a demand shock being seen in the form of price changes rather than changes in seats supplied. Price responses to airline shocks are considered below.

Whereas Table 4 reported the impact of terrorist attacks on seat-kilometres supplied by airlines (ASKs), Table 5 presents the impact of a terrorist shock on passenger demand (seats sold). The coefficient on the D30 variable indicated these demand effects to be more widespread than the supply impacts. Of the twelve attacks studied, demand fell in seven locations. The effect was especially marked in Copenhagen $(-10.1 \%)$ and Brussels $(-8.9 \%)$, in the latter case due in part to the airport's closure. Smaller falls in seats sales are observed in five other locations, mostly ranging from $-1 \%$ to $-2 \%$. As in the seat availability impact, some of the Table 5 estimates show a rise in supply, mostly on a modest scale (1\%-3\%), although supply in Berlin and Manchester rose by some $6 \%$.

\section{Insert Table 5 about here}

We next consider as to whether the impact of terrorist incidents might differ according to the continental origin of the flights. Table 6 presents the results estimated separately for US-originating and EU-originating traffic. Although the number of cities suffering a decline in both supply for air traffic following a terrorist attack is almost the same for EU and US services, the magnitudes of the changes are very different for some locations. In Turkey, for example, the shock produces a $20 \%$ fall in US-originating ASKs and a 19\% fall in US seat supply, whereas flights from EU cities fall by much smaller magnitudes: $5 \%$ in ASK terms and some $3 \%$ in seat supply. In Nice, in contrast, the impact of the attack is much great in Europe than in the United States. Both seat-kilometres and seats sold from European cities decline by over 30\%, whereas capacity and seats sold on USoriginating flights hardly change over the thirty days after the attack. In Copenhagen also, the impact of the shocks is much larger for EU- than US-originating traffic. Although US capacity and 
seats sold declined quite severely $(-6 \%)$, the reductions in traffic from the EU were twice as great $(-10 \%$ to $-12 \%)$.

\section{Insert Table 6 about here}

The continental origin of passengers also matters for explaining the impacts of the three terrorist attacks on Paris, with US-originating traffic in general more severely affected than European traffic. The 2015 Paris attacks were followed by declines of $2 \%-6 \%$ in US supply (though US traffic had risen $(+4 \%)$ after the 2013 Paris attack). For European traffic, the scale of the responses to the Paris attacks was smaller; declines of 0\%-3\%. The impact of the Brussels attack (and airport closure) was severe but comparable, with US impacts (-13\% to $-14 \%)$ not very much greater than for EU traffic $(-9 \%$ to $-12 \%)$. Other cities experienced increases in capacity and demand, with US traffic to Berlin accelerating by $45 \%-50 \%$.

The second stage of our analysis focuses on financial data, specifically the revenues and fares of airlines in the period after an attack on a European city. As explained above, these data are at a weekly frequency and available only for seven of the twelve cities considered in the initial analysis. Therefore Copenhagen (2015), Berlin (2016), Turkey (2016), Nice (2016) and Brussels (2016) are omitted from the remainder of the analysis.

\section{Insert Tables 7 and 8 about here}

Table 7 presents estimated for business seats sold and Table 8 gives the results for tourist seats sold. The dummy variable $\left(D_{t 30}\right)$ may be interpreted in these tables as the percentage change in traffic, 30 days after the attack, relative to what would be predicted based on existing trends and seasonal patterns. From Table 7 it may be seen that business seats sold fell in all locations that suffered an attack, including by very exceptional magnitudes in Paris. Thirty days after the January 2015 attack, our estimates indicate that business seats sold were down by $53 \%$ and by $70 \%$ after the attack later the same year (November). The next largest result relates to the 2013 Frankfurt attack where business seats sold were down by 15\%. In Stockholm and London, falls were more more modest (-5\%). On the tourist side of the industry, we observe a different pattern. First, only two cities experienced a decline in tourist seat sales (relative to forecast), these were after the second Paris attack $(-6 \%)$ and in Stockholm (-2\%). Notwithstanding the terrorist attacks, traffic rose in the other locations, with larger rises in Frankfurt $(+5 \%)$, Manchester $(+6 \%)$ and Paris $(2013 ;+9 \%)$.

Although it is not a hypothesis that we have been able to test for this paper, we suggest the following reasons for the contrasting estimates. Businesses have alternatives to air travel, 
in particular video conferencing, which might have been used until the terrorist risk diminished. Furthermore, a business might not wish or even be able to compel its staff to travel in the face of terrorist risks, while such businesses also have a corporate duty to safeguard the well-being of their employees, while tourist travellers might chose to make a trip despite the threat. These reasons might explain why tourism traffic was sustained but not business traffic following terrorist attacks over the period of investigation.

\section{Insert Table 9 about here}

Table 9 separates the effects of terrorist attacks on passengers by geography and by passenger type: business and tourist seats and EU- and US-originating flights. At the aggregate level, just discussed, the business response to the attacks was more widespread and larger than the tourist responses. Table 9 shows that most of this effect comes from EU rather than US business travellers. European business seats sold declined for all attacks. In three cases the declines were under 10\%, in Manchester (-3\%), Stockholm (-5\%) and London (-8\%). However, in the other cities, the impacts of the attacks on business travel were an order of magnitude larger: Frankfurt (-31\%) and both of the 2015 Paris attacks (January, -64\%; November -83\%). Undoubtedly, the terrorism events propagated far more media traction in Europe than it did in the United States as it was more localised and as a result, the rhetoric remained in the media for much longer when compared to media outlets the US. In contrast, US business seats sold rose in all locations bar Stockholm (-2\%) and the second Paris attack (-6\%). The increases ranged from 2\%-9\%. For tourist traffic, the different behaviour by European and US travellers is not repeated. Instead, the size and sign of the impacts are similar for European and US passengers. Tourists from both continents, in spite of the attacks, the number of visitors increased by between $1 \%$ and $6 \%$. (At Manchester, we estimate EU tourist demand rose by $21 \%$ following the attack). Where there were declines in seats sold (Paris, January 2015, about $-5 \%$ and Stockholm, $-0 \%$ to $2 \%$ ), the decline occurred for both EU and US passengers.

\section{Insert Table 10 about here}

Finally, we use the ARCH-GARCH regressions, as discussed in the methodology section of this paper, to examine the impact of the attacks on airline revenues and ticket prices. Table 10 shows that in nine of the ten locations reported, airline revenues declined following the terrorist shocks. If we disregard the cases of marginal declines (Berlin, Nice and London), revenues fell significantly in the other locations; Stockholm (-5\%), Paris $(-10 \%$ and $-22 \%$ for the earlier and later 2015 attacks), Manchester and Brussels (around -15\%) and very particularly in Turkey (-47\%), with serious commercial implications for both airlines and the tourism industry in that country. 
After the attacks, airlines cut ticket prices in all locations bar Copenhagen (where airline revenues rose). The largest reductions were in Manchester (-22\%) and Turkey (-13\%), but airlines serving other locations reduced ticket prices by some $-5 \%$ (Nice), around $-8 \%$ (Brussels and the later 2015 Paris attack), and about $-10 \%$ (Stockholm and London).

Table 11 subdivides the results by ticket class (business and economy/coach), as well as by the origin of the flight. $H_{5}$ investigates as to whether there is evidence of sustained pressures on airline revenues in the immediate aftermath of such instances of terrorism. The Table allows scrutiny of airlines' response to the attacks. Specifically, with expectations that there would be reduced demand to travel to such cities, airlines have the option to cancel such flights with detrimental reputational consequences (as those already booked and willing to fly will suffer through cancellations). Otherwise, the airline can reduce the ticket price by some or all ticket class to boost demand for the remaining seats and mitigate substantial expected losses.

\section{Insert Table 11 about here}

In Table 11, we observe the varying seasonally-adjusted responses to each attack. While there is no evidence of a uniform response to each, we can identify that seasonally-adjusted fare reductions are the most prevalent response, being broadly associated with reductions in airline revenues. In Table 11, it is important to note that most substantial ticket and fare responses, but also consider in isolation the responses to the most severe terrorist incidents. Business class ticketing was most effected in the aftermath of the Manchester bombings in 2017, with $60 \%$ and $55 \%$ reductions in ticket prices to entice customers in Europe and the US respectively. Premium and discount coach tickets experience similar extensive reductions in both revenues and fares in Europe during the Paris attacks of 2015, the Turkish coup of 2016, the Nice and Brussels attacks of 2016 and the Manchester bombings of 2017 respectively. The scale and sign of the responses provide evidence of a rational and responsive market, where the airline attempts to respond by filling the seats on their planned flights so as to mitigate extensive losses. Further, when investigating the results presented in Table 11 laterally, there is evidence to suggest that revenues suffered far more in European coach sales than that of business class which is further identified in the scale and frequency of the estimated reductions in ticket prices. However, in the US-sourced flights, there appears to be little evidence of a substantial difference between both revenues and ticket price adjustments when comparing coach and business class. Responses to both revenues and ticket pricing appear to be very much reliant on the bespoke nature of the individual terrorist attack. However, the evidence would suggest little

evidence provided of improvements in either business class, premium coach or discount coach across the majority of investigated cases. Our results offer little evidence to support a prudent tactical financial approach for airlines to consider in the aftermath of such an event apart from the limitation of losses through reduction of fares. The broad reduction of sales of business class ticket revenues 
provides further information that corporate entities cancel business trips following a terrorist attack for a prolonged period of time due to duty of care legislation and travel risk management. In the most extreme of events, discount and regular fare passengers appear to waive the opportunity to travel, even in situations where airlines reduce fares to loss-generating levels.

\section{Conclusions}

Although suffering throughout the aftermath of despicable actions in the form of terrorist attacks, one of the most important characteristics that is evident across a number of events is resilience. This resilience often takes the form of returning to normality as quick as possible. A broad number of countries in Europe rely on tourism and the maintenance of strong aviation routes from which they can prosper and thrive economically. Therefore, a significant shock to either sector can have significant ramifications. From a corporate point of view, this ethos is no different. Airlines have also experienced and survived the global financial crisis of 2007 while treading the depths of extremely difficult operating conditions during the oil price peaks of $\$ 147$ as investors fled to safety from tumbling stock markets. However, there is evidence of strong resilience of the European tourism and aviation industries during such periods of great distress.

Overall, the results of this paper could be summarised in the following six statements: 1) in the month after each attack, airlines serving some cities cut capacity; 2) customers responded faster, buying fewer tickets in about half the locations; 3) when traffic from the EU and the US are separated, it is found that different attacks affected US and EU traffic quite differently. For example, most of the reduction in passenger flows to Turkey and to the Paris attacks came from US passengers, whereas most of the response to the Nice attacks was on the part of Europeans passengers; 4) when business and tourist travellers are distinguished, it is seen that significant reductions in business travel is evident while tourist travel generally did not fall in the same manner, and in some cases actually increased in volume; 5) when traffic origin and ticket class are both taken into account, most of the decline in business purchases of seats is found to come from European business travellers; and finally 6) while investigating the impacts on airline revenues and ticket prices of the different terrorist incidents we find that while ticket prices were lowered by airlines, the magnitudes of the reductions were found to be very different and this is even more true for the declines in airline revenues.

There is evidence presented that businesses somewhat comply with duty of care legislation as it applies to corporate travel risk management and is portrayed through sharp reductions in business travel in the aftermath of terrorist incidents, a result that merits further attention and research in the future. Airlines with bases in the affected destination, along with airports and hotels are more affected due to the locality of their operations and spatial dependence. Tourism businesses affected by the attacks do not have a high negotiating power over possible financial compensation 
and bailouts due to their low market concentration, whereas airports and airlines with high route frequencies to the destination can put more pressure on local authorities, thereby possessing a higher probability of bargaining success. This is also an interesting area for future research. Finally, the results of such research would perhaps interest policy-makers who might face demands to provide financial assistance in the form of bailouts to mitigate such severe secondary effects.

Finally, while tourism and aviation industries operate in an extremely competitive market, there appears to be a strong inverse correlation between the atrocity of the terrorist incident and the corporate damage and revenue loss that occurs in the short-term thereafter, regardless of pricing structures that are implemented. Although major cities and companies may continue to operate through the size and scale of their operations, terrorist attacks that focus on smaller cities and routes such as those witnessed in Nice and Manchester generated chaos through the attack itself, but also severely impacted the local economy and society in the period thereafter, as fewer people travel to these areas. This effect will be directly related to such an area's reliance on tourism.

\section{References}

Araña, J. E. and C. J. León (2008). The impact of terrorism on tourism demand. Annals of Tourism Research 35(2), 299-315.

Bassil, C. (2014). The effect of terrorism on tourism demand in the middle east. Peace Economics, Peace Science and Public Policy 20(4), 669-684.

Bhattarai, K., D. Conway, and N. Shrestha (2005). Tourism, terrorism and turmoil in nepal. Annals of Tourism Research 32(3), 669-688.

Bieger, T. and A. Wittmer (2006). Air transport and tourism: Perspectives and challenges for destinations, airlines and governments. Journal of air transport management 12(1), 40-46.

Bollerslev, T. (1986). Generalized autoregressive conditional heteroskedasticity. Journal of econometrics 31(3), 307-327.

Chen, A. H. and T. F. Siems (2004). The effects of terrorism on global capital markets. European journal of political economy 20(2), 349-366.

Chen, Z., A. Z. Rose, F. Prager, and S. Chatterjee (2017). Economic consequences of aviation system disruptions: a reduced-form computable general equilibrium analysis. Transportation Research Part A: Policy and Practice 95, 207-226.

Cockburn, P. (2015). The rise of Islamic State: ISIS and the new Sunni revolution. Verso Books. 
Corbet, S. (2016). Turning Tigers into PIIGS: The Role of Leverage in the Irish Economic Collapse. In Lessons from the Great Recession: At the Crossroads of Sustainability and Recovery, pp. 21-55. Emerald Group Publishing Limited.

Corbet, S., C. Gurdgiev, and A. Meegan (2018). Long-term stock market volatility and the influence of terrorist attacks in europe. The Quarterly Review of Economics and Finance 68, 118-131.

Corbet, S. and C. J. Larkin (2018). Populism and extremism: The immediate political challenges to europeanism. Geoforum, Forthcoming.

Crenshaw, M. (1981). The causes of terrorism. Comparative politics 13(4), 379-399.

Dobruszkes, F., V. Mondou, and A. Ghedira (2016). Assessing the impacts of aviation liberalisation on tourism: Some methodological considerations derived from the moroccan and tunisian cases. Journal of Transport Geography 50, 115-127.

Drakos, K. (2004). Terrorism-induced structural shifts in financial risk: airline stocks in the aftermath of the september 11th terror attacks. European Journal of Political Economy 20(2), $435-446$.

Duval, D. T. (2007). Tourism and transport: Modes, networks and flows. Channel View Publications.

Duval, D. T. (2013). Critical issues in air transport and tourism. Tourism Geographies 15(3), 494-510.

Efthymiou, M. and A. Papatheodorou (2015). Intermodal passenger transport and destination competitiveness in greece. Anatolia 26(3), 459-471.

Efthymiou, M. and A. Papatheodorou (2018). Evolving airline and airport business models. In The Routledge Companion to Air Transport Management, pp. 122-135. Routledge.

Eldor, R. and R. Melnick (2004). Financial markets and terrorism. European Journal of Political Economy 20(2), 367-386.

Engle, R. F. (1982). Autoregressive conditional heteroscedasticity with estimates of the variance of united kingdom inflation. Econometrica: Journal of the Econometric Society, 987-1007.

Faulkner, B. (2001). Towards a framework for tourism disaster management. Tourism management 22(2), 135-147.

Fleischer, A. and S. Buccola (2002). War, terror, and the tourism market in Israel. Applied Economics 34(11), 1335-1343. 
Forsyth, P. (2006). Martin Kunz Memorial Lecture. Tourism benefits and aviation policy. Journal of Air Transport Management 12(1), 3-13.

Fox, S. (2014). Safety and security: The influence of $9 / 11$ to the EU framework for air carriers and aircraft operators. Research in Transportation Economics 45, 24-33.

Gates, S. and S. Podder (2015). Social Media, Recruitment, Allegiance and the Islamic State. Perspectives on Terrorism 9(4), 107-116.

Gillen, D. and A. Lall (2003). International transmission of shocks in the airline industry. Journal of Air Transport Management 9(1), 37-49.

Glazzard, A. (2015). ISIS: The State of Terror. The RUSI Journal 160(4), 85-87.

Goodrich, J. N. (2002). September 11, 2001 attack on america: a record of the immediate impacts and reactions in the usa travel and tourism industry. Tourism Management 23(6), 573-580.

Hall, C. M. (2010). Crisis events in tourism: subjects of crisis in tourism. Current issues in Tourism 13(5), 401-417.

Hamadeh, M. and C. Bassil (2017). Terrorism, war, and volatility in tourist arrivals: The case of lebanon. Tourism Analysis 22(4), 537-550.

Hoffman, B. (2006). Inside Terrorism. Political Science Quarterly 114, 432.

IATA (2011). The Impact of September 112001 on Aviation.

Jongman, A. J. (2017). Political terrorism: A new guide to actors, authors, concepts, data bases, theories. Routledge.

Khadaroo, J. and B. Seetanah (2008). The role of transport infrastructure in international tourism development: A gravity model approach. Tourism Management 29(5), 831-840.

Khazai, B., F. Mahdavian, and S. Platt (2017). Tourism recovery scorecard-benchmarking and monitoring progress on disaster recovery in tourism destinations. International Journal of Disaster Risk Reduction.

Koo, T. T., T. H. Rashidi, J.-W. Park, C.-L. Wu, and W.-C. Tseng (2017). The effect of enhanced international air access on the demand for peripheral tourism destinations: Evidence from air itinerary choice behaviour of korean visitors to australia. Transportation Research Part A: Policy and Practice 106, 116-129.

Leiper, N. (1979). The framework of tourism: Towards a definition of tourism, tourist, and the tourist industry. Annals of tourism research 6(4), 390-407. 
Liu, A. and S. Pratt (2017). Tourism's vulnerability and resilience to terrorism. Tourism Management 60, 404-417.

Marsden, S. V. and A. P. Schmid (2011). Typologies of terrorism and political violence. Routledge Handbooks Online.

Martin, G. (2017). Understanding terrorism: Challenges, perspectives, and issues. SAGE publications.

Mo, C.-M., D. R. Howard, and M. E. Havitz (1993). Testing an international tourist role typology. Annals of tourism research 20(2), 319-335.

Neumayer, E. and T. Plümper (2016). Spatial spill-overs from terrorism on tourism: Western victims in islamic destination countries. Public Choice 169(3-4), 195-206.

Page, S. (2005). Transport and tourism: Global perspectives. Pearson Education.

Page, S. (2011). Tourism management: An introduction. Routledge.

Papatheodorou, A. (2002). Civil aviation regimes and leisure tourism in Europe. Journal of Air Transport Management 8(6), 381-388.

Pizam, A. and A. Fleischer (2002). Severity versus frequency of acts of terrorism: Which has a larger impact on tourism demand? Journal of Travel Research 40(3), 337-339.

Prideaux, B. (2000). The role of the transport system in destination development. Tourism Management 21(1), 53-63.

Rehman, J. (2005). Islamic state practices, international law and the threat from terrorism: a critique of the'clash of civilizations' in the new world order, Volume 7. Hart Publishing.

Saha, S. and G. Yap (2014). The moderation effects of political instability and terrorism on tourism development: A cross-country panel analysis. Journal of Travel Research 53(4), 509-521.

Silke, A. (2003). Research on Terrorism: Trends, achievements and failures.

Sönmez, S. F. (1998). Tourism, terrorism, and political instability. Annals of Tourism Research $25(2), 416-456$.

Sönmez, S. F., Y. Apostolopoulos, and P. Tarlow (1999). Tourism in crisis: Managing the effects of terrorism. Journal of travel research 38(1), 13-18.

Stabler, M. J., A. Papatheodorou, and M. T. Sinclair (2009). The economics of tourism. 
Walters, G., R. Shipway, L. Miles, M. Aldrigui, et al. (2017). Fandom and risk perceptions of olympic tourists. Annals of Tourism Research 66, 210-212.

Wolff, K. and S. Larsen (2014). Can terrorism make us feel safer? risk perceptions and worries before and after the july 22nd attacks. Annals of Tourism Research 44, 200-209.

Yechiam, E., G. Barron, and I. Erev (2005). The role of personal experience in contributing to different patterns of response to rare terrorist attacks. Journal of Conflict Resolution 49(3), 430-439. 


\section{Appendix 1}

As volatility of a series does not generally remain constant through time, periods of both high and low volatility are grouped together. ARCH, as introduced by Engle [1982], used conditional maximum likelihood which is computed based on an estimated set of priming values for the squared innovations $\varepsilon_{t}^{2}$ and variances $\sigma_{t}^{2}$. The original model used the variance of a regression model's disturbances as a linear function of lagged values of the squared disturbances, written as the conditional mean and conditional variance equation respectively:

$$
\begin{gathered}
y_{t}=x_{t} \beta+\varepsilon_{t} \\
\sigma_{t}^{2}=\gamma_{0}+\gamma_{1} \varepsilon_{t-1}^{2}+\gamma_{2} \varepsilon_{t-2}^{2}+\ldots+\gamma_{p} \varepsilon_{t-p}^{2}
\end{gathered}
$$

where $\varepsilon_{t-1}^{2}$ and $\gamma_{i}$ represent the squared residuals and ARCH parameters respectively. The variance is a function of the size of the prior unanticipated innovations as measured by $\varepsilon_{t}$. Bollerslev [1986] generalised the methodology to include lagged values of the conditional variance, written as the $\operatorname{GARCH}(\mathrm{p}, \mathrm{q})$ model:

$$
\begin{gathered}
y_{t}=x_{t} \beta+\varepsilon_{t} \\
\sigma_{t}^{2}=\gamma_{0}+\gamma_{1} \varepsilon_{t-1}^{2}+\gamma_{2} \varepsilon_{t-2}^{2}+\ldots+\gamma_{p} \varepsilon_{t-p}^{2}+\delta_{1} \sigma_{t-1}^{2}+\delta_{2} \sigma_{t-2}^{2}+\ldots+\delta_{q} \sigma_{t-q}^{2}
\end{gathered}
$$

where $\gamma_{i}$ are the ARCH parameters and $\delta_{i}$ are the GARCH parameters. The GARCH model of conditional variance can be considered an ARMA process in the squared innovations. The general linear ARMA $(\mathrm{r}, \mathrm{m})$ model for conditional mean can be expressed as:

$$
y_{t}=c+\sum_{i=1}^{r} \phi_{i} y_{t-i}+\sum_{j=1}^{m} \theta_{j} \varepsilon_{t-j}+\varepsilon_{t}
$$

where $y_{t}$ takes the value of the time series that we are modelling, $c$ is a constant, $r$ is the number of autoregressive orders, $m$ is the number of moving average orders, $\phi_{i}$ is the autoregressive coefficient, $\theta_{j}$ is the moving average coefficient and $\varepsilon_{t}$ is the error. The term $c+\sum_{i=1}^{r} \phi_{i} y_{t-i}+$ $\sum_{j=1}^{m} \theta_{j} \varepsilon_{t-j}+\varepsilon_{t}$ is the deterministic component that presents a forecast of the current state as the functions of past observations and errors. The error term is the random component which is otherwise described as the innovation. The conditional variance of the innovations is defined:

$$
\sigma_{t}^{2}=\operatorname{Var}_{t-1}\left(\varepsilon_{t}\right)=E_{t-1}\left(\varepsilon_{t}^{2}\right)
$$

The general $\operatorname{GARCH}(\mathrm{p}, \mathrm{q})$ model for the conditional variance of innovations $\varepsilon_{t}$ is: 


$$
\sigma_{t}^{2}=k+\sum_{i=1}^{p} G_{i} \sigma_{t-i}^{2}+\sum_{j=1}^{q} A_{j} \varepsilon_{t-j}^{2}
$$

with the constraints $\sum_{i=1}^{p} G_{i}+\sum_{j=1}^{q} A_{j}<1, k>0, G_{i} \geq 0$ where $(i=1,2, \ldots, p)$ and $A_{j} \geq 0$ where $(j=1,2, \ldots, q)$. Due to the presence of seasonality in our data based on passenger numbers, total airline revenues (by route) and airline fares we retain the $\operatorname{GARCH}(1,1)$ specification for the conditional variance and model the mean as an ARMA process with $\mathrm{AR}(1)$ and $\mathrm{MA}(1)$ as well as controlled lags in the MA-specification to control for seasonal effects at the annual level, that is, summer traffic is controlled for previous summer periods and winter traffic is controlled for previous winter periods. The ARMA/GARCH model for the variance model can be summarised by the following equations, where $D_{t}$ represents a dummy variable signalling the terrorist attack:

$$
\begin{gathered}
y_{t}=c+\sum_{i=1}^{r} \phi_{i} y_{t-i}+\sum_{j=1}^{m} \theta_{j} \varepsilon_{t-j}+D_{t}+\varepsilon_{t}, \text { where } \varepsilon_{t} \sim N\left(0, \sigma_{t}^{2}\right) \\
\sigma_{t}^{2}=k+\sum_{i=1}^{p} G_{i} \sigma_{t-i}^{2}+\sum_{j=1}^{q} A_{j} \varepsilon_{t-j}^{2}, \text { where } \varepsilon_{t}=\sigma_{t} z_{t} \text { and } z_{t} \sim N(0,1)
\end{gathered}
$$


Figure 1: The geographic dispersion of the selected major terrorist incidents between 2011 and 2018

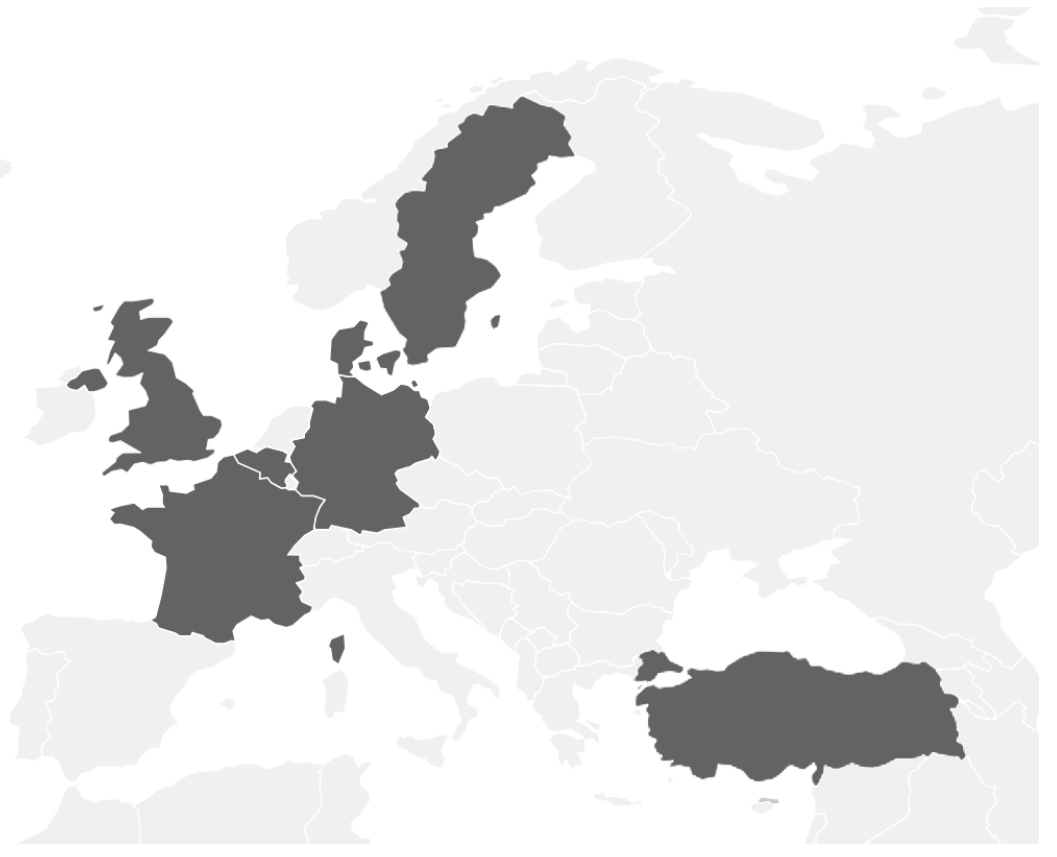

Note: The shaded regions in the map above indicate the countries in which a terrorist attack included in our analysis had occurred. These events are explained in further detail in Table 1. 
Table 1: Selected European terrorism incidents (2011-2018)

\begin{tabular}{|c|c|c|c|c|}
\hline Date & Location & Killed & Injured & Description \\
\hline 02-Mar-11 & $\begin{array}{l}\text { Frankfurt, } \\
\text { Germany }\end{array}$ & 2 & 2 & $\begin{array}{l}\text { Arid Uka, was arrested and charged with killing two United States Airmen and seriously wounding two others at Frankfurt } \\
\text { Airport in Germany. He was sentenced to life in prison on } 10 \text { February } 2012 \text {. }\end{array}$ \\
\hline 15-Nov-13 & Paris, France & 0 & 1 & $\begin{array}{l}\text { On November } 15,2013 \text {, a gunman attacked the offices of the BFM TV news channel, in Paris, France. Three days later, } \\
\text { on November } 18 \text {, the same gunman attacked the offices of the Liberation newspaper and the headquarters of the Societe } \\
\text { Generale bank. }\end{array}$ \\
\hline 07-Jan-15 & Paris, France & 20 & 22 & $\begin{array}{l}\text { The attacks began on } 7 \text { January, when two gunmen attacked the headquarters of the satirical newspaper Charlie Hebdo, } \\
\text { killing } 12 \text { people and wounding } 12 \text { others before escaping. }\end{array}$ \\
\hline 14-Feb-15 & $\begin{array}{l}\text { Copenhagen, } \\
\text { Denmark }\end{array}$ & 3 & 5 & On 14 and 15 February 2015, three separate shootings occurred in Copenhagen, Denmark. \\
\hline 13-Nov-15 & Paris, France & 137 & 413 & $\begin{array}{l}\text { Beginning at } 21: 16 \text { CET, three suicide bombers struck outside the Stade e France in Saint-Denis, during a football match. } \\
\text { This was followed by several mass shootings and a suicide bombing, at cafã } \text { Irs and restaurants. Gunmen carried out another } \text { mass shooting and took hostages at an Eagles of Death Metal concert in the Bataclan theatre. }\end{array}$ \\
\hline 22-Mar-16 & $\begin{array}{l}\text { Brussels, Bel- } \\
\text { gium }\end{array}$ & 35 & 340 & $\begin{array}{l}\text { On the morning of } 22 \text { March 2016, three coordinated suicide bombings occurred in Belgium: two at Brussels Airport in } \\
\text { Zaventem, and one at Maalbeek metro station in central Brussels. }\end{array}$ \\
\hline 14-Jul-16 & Nice, France & 87 & 434 & $\begin{array}{l}\text { On the evening of } 14 \text { July } 2016 \text {, a } 19 \text { tonne cargo truck was deliberately driven into crowds of people celebrating Bastille } \\
\text { Day on the Promenade des Anglais in Nice, France, resulting in the deaths of } 86 \text { people and the injury of } 458 \text { others. }\end{array}$ \\
\hline 15-Jul-16 & Turkey & est $>300$ & 2,185 & $\begin{array}{l}\text { On } 15 \text { July } 2016 \text {, a coup d'Ãrtat was attempted in Turkey against state institutions, including the government and President } \\
\text { Recep Tayyip Erdogan. The attempt was carried out by a faction within the Turkish Armed Forces that organized themselves } \\
\text { as the Peace at Home Council. }\end{array}$ \\
\hline 19-Dec-16 & $\begin{array}{l}\text { Berlin, Ger- } \\
\text { many }\end{array}$ & 12 & 56 & $\begin{array}{l}\text { On } 19 \text { December 2016, a truck was deliberately driven into the Christmas market next to the Kaiser Wilhelm Memorial } \\
\text { Church at Breitscheidplatz in Berlin, leaving } 12 \text { people dead and } 56 \text { others injured. }\end{array}$ \\
\hline 22-Mar-17 & $\begin{array}{l}\text { London, } \\
\text { United King- } \\
\text { dom }\end{array}$ & 6 & 49 & On 22 March 2017, a terrorist attack took place outside the Palace of Westminster in London, seat of the British Parliament. \\
\hline 07-Apr-17 & $\begin{array}{l}\text { Stockholm, } \\
\text { Sweden }\end{array}$ & 5 & 14 & $\begin{array}{l}\text { On } 7 \text { April } 2017 \text {, in central Stockholm, the capital of Sweden, a hijacked lorry was deliberately driven into crowds. Five } \\
\text { people were killed and } 14 \text { others were seriously injured. Police considered the attack an act of terrorism. Rakhmat Akilov, } \\
\text { a } 39 \text {-year-old citizen of Uzbekistan, was apprehended the same day. }\end{array}$ \\
\hline 22-May-17 & $\begin{array}{l}\text { Manchester, } \\
\text { United King- } \\
\text { dom }\end{array}$ & 23 & 512 & $\begin{array}{l}\text { The attack took place after an Ariana Grande concert on } 22 \text { May 2017. 14,200 people attended the concert. Greater Manch- } \\
\text { ester Police declared the incident a terrorist attack and suicide bombing. Twenty-three people were killed, including the } \\
\text { attacker, and over } 500 \text { were injured. }\end{array}$ \\
\hline
\end{tabular}


Table 2: Daily average values for ASKs and seats sold data used for each attack

\begin{tabular}{|c|c|c|c|c|c|c|c|}
\hline Country & City & Sample & Route & $\begin{array}{c}\text { Average } \\
\text { ASKs }\end{array}$ & $\begin{array}{c}\text { Average } \\
\text { Business Seats } \\
\end{array}$ & $\begin{array}{c}\text { Average } \\
\text { Economy Seats } \\
\end{array}$ & $\begin{array}{l}\text { Average of } \\
\text { Total Seats } \\
\end{array}$ \\
\hline Germany & Frankfurt & $\begin{array}{l}\text { Sep } 2009 \text { - } \\
\text { Sep } 2013\end{array}$ & $\begin{array}{l}\text { US } \\
\text { Europe } \\
\text { Total }\end{array}$ & $\begin{array}{c}94,921,623 \\
57,261,633 \\
152,183,256\end{array}$ & $\begin{array}{l}2,148 \\
2,021 \\
4,169\end{array}$ & $\begin{array}{l}10,749 \\
61,954 \\
72,703\end{array}$ & $\begin{array}{l}13,238 \\
63,992 \\
77,230\end{array}$ \\
\hline France & Paris & $\begin{array}{l}\text { May } 2012 \text { - } \\
\text { May } 2015\end{array}$ & $\begin{array}{l}\text { US } \\
\text { Europe } \\
\text { Total }\end{array}$ & $\begin{array}{c}85,085,973 \\
90,037,510 \\
175,123,483\end{array}$ & $\begin{array}{l}1,490 \\
7,383 \\
8,873\end{array}$ & $\begin{array}{c}11,170 \\
92,675 \\
103,845\end{array}$ & $\begin{array}{c}12,893 \\
100,075 \\
112,968\end{array}$ \\
\hline Denmark & Copenhagen & $\begin{array}{l}\text { Aug } 2013- \\
\text { Aug } 2016\end{array}$ & $\begin{array}{l}\text { US } \\
\text { Europe } \\
\text { Total }\end{array}$ & $\begin{array}{l}12,010,173 \\
38,772,492 \\
50,782,665\end{array}$ & $\begin{array}{l}- \\
-\end{array}$ & $\begin{array}{l}- \\
-\end{array}$ & $\begin{array}{c}1,825 \\
42,070 \\
43,895\end{array}$ \\
\hline France & Paris & $\begin{array}{l}\text { Jul } 2013- \\
\text { Jul } 2016\end{array}$ & $\begin{array}{l}\text { US } \\
\text { Europe } \\
\text { Total }\end{array}$ & $\begin{array}{c}91,987,740 \\
90,399,136 \\
182,386,876\end{array}$ & $\begin{array}{l}1,793 \\
8,134 \\
9,927\end{array}$ & $\begin{array}{c}11,976 \\
88,798 \\
100,774\end{array}$ & $\begin{array}{c}13,846 \\
97,106 \\
110,952\end{array}$ \\
\hline Germany & Berlin & $\begin{array}{l}\text { Jun } 2015 \text { - } \\
\text { Mar } 2018\end{array}$ & $\begin{array}{l}\text { US } \\
\text { Europe } \\
\text { Total }\end{array}$ & $\begin{array}{c}5,326,572 \\
50,566,872 \\
55,893,444\end{array}$ & $\begin{array}{l}- \\
-\end{array}$ & $\begin{array}{l}- \\
-\end{array}$ & $\begin{array}{c}783 \\
53,113 \\
53,896\end{array}$ \\
\hline France & Nice & $\begin{array}{l}\text { Jan } 2015- \\
\text { Jan } 2018\end{array}$ & $\begin{array}{l}\text { US } \\
\text { Europe } \\
\text { Total }\end{array}$ & $\begin{array}{c}2,095,799 \\
17,866,406 \\
19,962,205\end{array}$ & $\begin{array}{l}- \\
-\end{array}$ & $\begin{array}{l}- \\
-\end{array}$ & $\begin{array}{c}331 \\
20,625 \\
20,956\end{array}$ \\
\hline Turkey & Istanbul & $\begin{array}{l}\text { Jan } 2015- \\
\text { Jan } 2018\end{array}$ & $\begin{array}{l}\text { US } \\
\text { Europe } \\
\text { Total }\end{array}$ & $\begin{array}{c}32,768,152 \\
324,118,588 \\
356,856,896\end{array}$ & $\begin{array}{l}- \\
- \\
-\end{array}$ & $\begin{array}{l}- \\
- \\
-\end{array}$ & $\begin{array}{c}3,640 \\
321,626 \\
325,263\end{array}$ \\
\hline Belgium & Brussels & $\begin{array}{l}\text { Sept } 2014 \text { - } \\
\text { Sept } 2017\end{array}$ & $\begin{array}{l}\text { US } \\
\text { Europe } \\
\text { Total }\end{array}$ & $\begin{array}{l}13,782,683 \\
49,451,097 \\
63,233,780\end{array}$ & $\begin{array}{l}- \\
-\end{array}$ & $\begin{array}{l}- \\
- \\
-\end{array}$ & $\begin{array}{c}2,256 \\
43,668 \\
45,924\end{array}$ \\
\hline Sweden & Stockholm & $\begin{array}{l}\text { Oct } 2015- \\
\text { Mar } 2018\end{array}$ & $\begin{array}{l}\text { US } \\
\text { Europe } \\
\text { Total }\end{array}$ & $\begin{array}{c}9,628,961 \\
53,800,522 \\
63,429,483\end{array}$ & $\begin{array}{c}152 \\
3,175 \\
3,327\end{array}$ & $\begin{array}{c}1,152 \\
47,551 \\
48,703\end{array}$ & $\begin{array}{c}1,304 \\
50,813 \\
52,117\end{array}$ \\
\hline UK & London & $\begin{array}{l}\text { Aug } 2015- \\
\text { Mar } 2018\end{array}$ & $\begin{array}{l}\text { US } \\
\text { Europe } \\
\text { Total }\end{array}$ & $\begin{array}{l}238,886,919 \\
172,910,873 \\
411,797,792\end{array}$ & $\begin{array}{c}5,518 \\
6,846 \\
12,363\end{array}$ & $\begin{array}{c}29,480 \\
140,570 \\
170,050\end{array}$ & $\begin{array}{c}35,634 \\
147,588 \\
183,222\end{array}$ \\
\hline UK & Manchester & $\begin{array}{l}\text { Nov } 2014- \\
\text { Mar } 2018\end{array}$ & $\begin{array}{l}\text { US } \\
\text { Europe } \\
\text { Total }\end{array}$ & $\begin{array}{l}48,432,191 \\
19,575,646 \\
68,007,837\end{array}$ & $\begin{array}{c}976 \\
173 \\
1,148\end{array}$ & $\begin{array}{c}33,514 \\
2,884 \\
36,398\end{array}$ & $\begin{array}{c}34,491 \\
3,057 \\
37,547\end{array}$ \\
\hline
\end{tabular}

Note: The above table presents the average values of the key variables used in our selected methodology for each of the terrorist attacks. Each sample includes all airports within each of the investigated cities. Missing values denote countries for which no data was available. EU and US denote flights that originated in either Europe and the United States within the stated time frame. ASKs are Available Seat Kilometres which is a measure of passenger carrying capacity on a given route. The inclusion of distance in the ASK measure accounts for the difference in scale vis-a-vis the seats data. 
Table 3: Average fares by city and month, and continental origin of traffic

\begin{tabular}{|c|c|c|c|c|c|c|c|c|c|c|c|c|}
\hline \multirow{2}{*}{\multicolumn{13}{|c|}{ European Union }} \\
\hline & & & & & & & & & & & & \\
\hline Paris Jan 2015 & $\$ 214$ & $\$ 213$ & $\$ 207$ & $\$ 212$ & $\$ 218$ & $\$ 210$ & $\$ 203$ & $\$ 209$ & $\$ 215$ & $\$ 222$ & & \\
\hline Copenhagen 2015 & $\$ 318$ & $\$ 302$ & & $\$ 284$ & $\$ 285$ & $\$ 291$ & $\$ 303$ & $\$ 280$ & & $\$ 306$ & $\$ 332$ & $\$ 319$ \\
\hline Paris Nov 2015 & & $\$ 209$ & $\$ 194$ & & & & $\$ 206$ & $\$ 204$ & $\$ 214$ & $\$ 221$ & $\$ 216$ & $\$ 199$ \\
\hline Berlin 2016 & $\$ 206$ & & $\$ 188$ & $\$ 162$ & $\$ 197$ & $\$ 180$ & $\$ 170$ & $\$ 173$ & $\$ 186$ & $\$ 193$ & $\$ 247$ & $\$ 231$ \\
\hline Turkey 2016 & $\$ 451$ & $\$ 450$ & $\$ 449$ & $\$ 435$ & $\$ 481$ & $\$ 461$ & $\$ 440$ & $\$ 482$ & $\$ 458$ & $\$ 431$ & $\$ 428$ & $\$ 406$ \\
\hline Nice 2016 & $\$ 381$ & $\$ 377$ & $\$ 319$ & $\$ 327$ & $\$ 366$ & $\$ 370$ & $\$ 372$ & $\$ 348$ & $\$ 331$ & $\$ 326$ & $\$ 379$ & $\$ 339$ \\
\hline Brussels 2016 & $\$ 261$ & $\$ 245$ & $\$ 285$ & $\$ 264$ & $\$ 267$ & $\$ 251$ & $\$ 278$ & $\$ 250$ & $\$ 255$ & $\$ 266$ & $\$ 251$ & $\$ 219$ \\
\hline $\begin{array}{l}\text { Manchester } 2017 \\
\text { Stockholm } 2017\end{array}$ & - \$250 & - $\$ 302$ & $\$ \$ 275$ & $\begin{array}{l}\$ 278 \\
\$ 177\end{array}$ & - $\$ 271$ & $\begin{array}{l}\$ 286 \\
\$ 193\end{array}$ & $\begin{array}{l}\$ 244 \\
\$ 197\end{array}$ & $\$ \$ 181$ & \$183 & -\$270 & $\$ 329$ & $\$ 257$ \\
\hline $\begin{array}{l}\text { Stockholm } 2017 \\
\text { London } 2017\end{array}$ & $\begin{array}{l}\$ 186 \\
\$ 271\end{array}$ & $\begin{array}{l}\$ 259 \\
\$ 260\end{array}$ & $\begin{array}{l}\$ 210 \\
\$ 220\end{array}$ & $\begin{array}{l}\$ 177 \\
\$ 216\end{array}$ & $\begin{array}{l}\$ 172 \\
\$ 260\end{array}$ & $\begin{array}{l}\$ 193 \\
\$ 237\end{array}$ & $\begin{array}{l}\$ 197 \\
\$ 274\end{array}$ & $\begin{array}{l}\$ 181 \\
\$ 221\end{array}$ & $\begin{array}{l}\$ 183 \\
\$ 285\end{array}$ & $\begin{array}{l}\$ 179 \\
\$ 324\end{array}$ & $\$ \$ \$ 329$ & $\$ \$ 263$ \\
\hline \multicolumn{13}{|l|}{ United States } \\
\hline Paris Jan 2015 & $\$ 1,802$ & $\$ 1,570$ & $\$ 1,840$ & $\$ 1,660$ & $\$ 1,991$ & $\$ 2,101$ & $\$ 1,614$ & $\$ 1,593$ & $\$ 1,793$ & $\$ 1,660$ & $\$ 1,728$ & $\$ 2,071$ \\
\hline Copenhagen 2015 & $\$ 1,726$ & $\$ 1,782$ & $\$ 1,629$ & $\$ 1,706$ & $\$ 1,500$ & $\$ 1,772$ & $\$ 1,526$ & $\$ 1,625$ & $\$ 1,986$ & $\$ 2,032$ & $\$ 1,720$ & $\$ 1,613$ \\
\hline Paris Nov 2015 & $\$ 1,961$ & $\$ 2,525$ & $\$ 1,907$ & & $\$ 1,949$ & & $\$ 1,646$ & & & $\$ 1,655$ & $\$ 1,827$ & $\$ 2,428$ \\
\hline Berlin 2016 & $\$ 1,740$ & $\$ 2,110$ & $\$ 1,741$ & $\$ 1,573$ & $\$ 1,497$ & $\$ 1,787$ & $\$ 1,445$ & $\$ 1,322$ & $\$ 1,406$ & $\$ 1,577$ & $\$ 1,909$ & $\$ 1,723$ \\
\hline Turkey 2016 & $\begin{array}{l}\$ 1,509 \\
\$ 3,482\end{array}$ & $\$ 1,442$ & $\begin{array}{l}\$ 1,438 \\
\$ \$, 608\end{array}$ & $\begin{array}{l}\$ 1,489 \\
\$ 2,320\end{array}$ & $\begin{array}{l}\$ 1,446 \\
\$ 2,700\end{array}$ & $\begin{array}{l}\$ 1,576 \\
\$ 3,275\end{array}$ & $\begin{array}{l}\$ 1,294 \\
\$ 2,556\end{array}$ & $\$ \$ 1,511$ & $\begin{array}{l}\$ 1,372 \\
\$ 2,236\end{array}$ & $\$ 1,317$ & $\$ 1,459$ & - $\$ 1,634$ \\
\hline $\begin{array}{l}\text { Nice } 20 \\
\text { Brussel }\end{array}$ & $\$ \$ \$ 1,664$ & $\begin{array}{l}\$ 4,211 \\
\$ 1,704\end{array}$ & $\begin{array}{l}\$, 2,608 \\
\$ 1,682\end{array}$ & $\$$ & $\$ \$ 1,563$ & $\begin{array}{l}\$ 3,770 \\
\$ 1,759\end{array}$ & $\begin{array}{l}\$ 2,506 \\
\$ 1,594\end{array}$ & $\$ \$ 1,626$ & 作 & 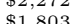 & 作 & $\$ 1,450$ \\
\hline Manchester 2017 & \$1,242 & \$1,521 & $\$ \$ 1,477$ & \$1,241 & (\$1,485 & $\$ \$ 1,399$ & \$1,358 & $\$ 1,318$ & 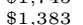 & $\$$ & $\$ 1,453$ & $\$ 1,187$ \\
\hline Stockholm 2017 & $\$ 1,314$ & $\$ 1,703$ & $\$ 1,395$ & $\$ 1,386$ & $\$ 1,571$ & $\$ 2,107$ & $\$ 1,306$ & $\$ \$ 1,294$ & $\$$ & $\$ \$ 3,670$ & $\$ \$ 1,625$ & $\$ 2,555$ \\
\hline London 2017 & $\$ 1,698$ & $\$ 1,814$ & $\$ 1,394$ & $\$ 1,370$ & $\$ 1,559$ & $\$ 1,772$ & $\$ 1,448$ & $\$ 1,902$ & $\$ 1,539$ & $\$ 1,405$ & $\$ 1,582$ & $\$ 1,568$ \\
\hline
\end{tabular}

Note: The table represents the average airline fares by city, month of the year, and distinguishing traffic with an origin in Europe from that
with an origin in the United States. Fares are denoted in US $\$$ which is calculated at the time that the revenue is obtained. 
Table 4: The effects of terrorist attacks on ASKs

\begin{tabular}{|c|c|c|c|c|c|c|c|c|c|c|c|c|}
\hline & $\begin{array}{c}\text { Frankfurt } \\
2011 \\
\end{array}$ & $\begin{array}{l}\text { Paris } \\
2013\end{array}$ & $\begin{array}{c}\text { Paris } \\
\text { Jan 2015 } \\
\end{array}$ & $\begin{array}{c}\text { Copenh. } \\
2015\end{array}$ & $\begin{array}{c}\text { Paris } \\
\text { Nov 2015 } \\
\end{array}$ & $\begin{array}{c}\text { Berlin } \\
2016 \\
\end{array}$ & $\begin{array}{c}\text { Turkey } \\
2016\end{array}$ & $\begin{array}{l}\text { Nice } \\
2016\end{array}$ & $\begin{array}{c}\text { Brussels } \\
2016\end{array}$ & $\begin{array}{l}\text { Manch. } \\
2017\end{array}$ & $\begin{array}{l}\text { Stockh. } \\
2017\end{array}$ & $\begin{array}{c}\text { London } \\
2017\end{array}$ \\
\hline Constant & 1.8698 & 1.8840 & 1.8793 & 1.7572 & 1.8785 & 1.7710 & 1.8814 & 1.6455 & 1.7778 & 1.7508 & 1.7762 & 1.9679 \\
\hline Jan & $\begin{array}{r}(33.85) \\
-0.0429\end{array}$ & $\begin{array}{l}(32.19) \\
-0.007\end{array}$ & $(22.19)$ & $\begin{array}{l}(10.66) \\
-0.083)\end{array}$ & $\begin{array}{l}(23.71) \\
0.0282\end{array}$ & $\begin{array}{l}(15.31) \\
-0.072)\end{array}$ & $\begin{array}{l}(22.65) \\
0.0277\end{array}$ & $\begin{array}{l}(9.17) \\
-0.1537\end{array}$ & $\begin{array}{l}(18.08) \\
-0.040\end{array}$ & $\begin{array}{l}(1.14) \\
-0.067\end{array}$ & $\begin{array}{l}(13.85) \\
-0.0233\end{array}$ & $\begin{array}{l}(27.78) \\
-0.020\end{array}$ \\
\hline Jan & $\begin{array}{c}-0.0429 \\
(-5.97)\end{array}$ & $(-1.03)$ & $\begin{array}{l}.0244 \\
(2.27)\end{array}$ & $\begin{array}{l}-0.08099 \\
(-3.77)\end{array}$ & $\begin{array}{l}0.0263 \\
(2.63)\end{array}$ & $(-4.34)$ & $(2.47)$ & $\begin{array}{l}-0.153) \\
(-6.36)\end{array}$ & $\begin{array}{l}-0.040 t \\
(-3.06)\end{array}$ & $\begin{array}{c}-0.0671 \\
(-3.14)\end{array}$ & $(-1.31)$ & $\begin{array}{l}-0.020 \\
(-2.04)\end{array}$ \\
\hline Feb & - & - & - & - & - & - & - & - & - & - & - & - \\
\hline Mar & 0.0408 & 0.0534 & 0.0715 & 0.1202 & 0.0799 & 0.0593 & 0.0929 & 0.2474 & 0.0613 & 0.1573 & 0.0740 & 0.0656 \\
\hline & $\begin{array}{l}(4.94) \\
0.140\end{array}$ & $\begin{array}{l}(6.56) \\
0\end{array}$ & $(6.27)$ & $(4.92)$ & $\begin{array}{l}(7.26) \\
0.36\end{array}$ & $\begin{array}{l}(3.70) \\
0.140\end{array}$ & (8.04) & $(9.91)$ & $(4.48)$ & (7.37) & $(4.15)$ & (6.57) \\
\hline Apr & $\begin{array}{l}0.1424 \\
(18.39\end{array}$ & $\begin{array}{r}0.1435 \\
(1748)\end{array}$ & $\begin{array}{r}0.2276 \\
(19881\end{array}$ & $\begin{array}{l}0.2066 \\
(8.95)\end{array}$ & $\begin{array}{l}0.2361 \\
(21.25)\end{array}$ & $\begin{array}{l}0.1408 \\
(8.700\end{array}$ & $\begin{array}{l}0.2601 \\
(22.33\end{array}$ & 0.4664 & $\begin{array}{r}0.2372 \\
\end{array}$ & $\begin{array}{c}0.4602 \\
\end{array}$ & $\begin{array}{r}0.1850 \\
\end{array}$ & $\begin{array}{r}0.1676 \\
0\end{array}$ \\
\hline May & $\begin{array}{l}(18.39) \\
0.2098\end{array}$ & $\begin{array}{l}(1.48) \\
0.1982\end{array}$ & $\begin{array}{l}(19.81) \\
0.3068\end{array}$ & $\begin{array}{l}(8.95) \\
0.2523\end{array}$ & $\begin{array}{l}(21.25) \\
0.3153\end{array}$ & $\begin{array}{l}(8.70) \\
0.2047\end{array}$ & $\begin{array}{l}(22.33) \\
0.3497\end{array}$ & $\begin{array}{l}(18.53) \\
0.5332\end{array}$ & $\begin{array}{l}(15.75) \\
0.2484\end{array}$ & $\begin{array}{l}(21.39) \\
0.6919\end{array}$ & $\begin{array}{l}(10.27) \\
0.2384\end{array}$ & $\begin{array}{r}(16.23) \\
0.2404\end{array}$ \\
\hline & $\begin{array}{l}(27.31) \\
(27.31)\end{array}$ & $(24.47)$ & $(26.90)$ & (11.02) & $\begin{array}{l}0.0100 \\
(28.61)\end{array}$ & $(13.31)$ & $\begin{array}{l}(30.27) \\
\end{array}$ & $\begin{array}{l}(21.35) \\
\text { (2) }\end{array}$ & $\begin{array}{l}0.284 \\
(18.13)\end{array}$ & $\begin{array}{l}(.32 .01) \\
(32.01\end{array}$ & $(12.43)$ & $\begin{array}{l}0.2404 \\
(24.39)\end{array}$ \\
\hline Jun & 0.2592 & 0.2672 & 0.3949 & 0.3265 & 0.4034 & 0.2402 & 0.4321 & 0.6217 & 0.2978 & 0.8176 & 0.2991 & 0.2772 \\
\hline Jul & (33.46) & $\begin{array}{l}(32.56) \\
0.2866\end{array}$ & $(34.37)$ & $(14.14)$ & $(36.31)$ & $(14.01)$ & $(37.09)$ & $(24.68)$ & $(21.59)$ & $(36.57)$ & $(16.63)$ & \\
\hline Jul & $\begin{array}{l}0.2701 \\
(34.86)\end{array}$ & $\begin{array}{l}0.2866 \\
(34.92)\end{array}$ & $\begin{array}{l}0.4184 \\
0\end{array}$ & $\begin{array}{l}0.3433 \\
\end{array}$ & $\begin{array}{r}0.4269 \\
0\end{array}$ & $\begin{array}{r}0.2059 \\
\end{array}$ & 0.5048 & 0.6358 & 0.3459 & 0.8689 & 0.3455 & 0.2914 \\
\hline Aug & $\begin{array}{l}34.86) \\
0.2724\end{array}$ & $\begin{array}{c}(3.92) \\
0.2741\end{array}$ & $\begin{array}{l}(36.78) \\
0.4045\end{array}$ & $\begin{array}{l}(13.87) \\
0.3274)\end{array}$ & $\begin{array}{l}(38.83) \\
0.4129\end{array}$ & $\begin{array}{l}(12.72) \\
0.2030\end{array}$ & $\begin{array}{l}(39.18) \\
0.4934\end{array}$ & $\begin{array}{l}(23.04) \\
0.5686\end{array}$ & $\begin{array}{l}(25.08) \\
(3434)\end{array}$ & $\begin{array}{l}(40.39) \\
0\end{array}$ & $\begin{array}{l}(19.20) \\
0\end{array}$ & $\begin{array}{l}(29.32) \\
0.3027\end{array}$ \\
\hline & $(35.71)$ & $(33.92)$ & $(35.72)$ & $(15.09)$ & $(37.75)$ & $(12.75)$ & $(43.02)$ & $\begin{array}{l}0.5686 \\
(22.94)\end{array}$ & $\begin{array}{l}0.3434 \\
(25.29)\end{array}$ & $\begin{array}{l}0.8935 \\
(42.18)\end{array}$ & $\begin{array}{r}0.3363 \\
(18.999\end{array}$ & $\begin{array}{r}0.3027 \\
(30.95)\end{array}$ \\
\hline Sept & 0.2414 & 0.2297 & 0.3429 & 0.2025 & 0.3514 & 0.2359 & 0.4439 & 0.5245 & 0.3189 & 0.8352 & 0.3148 & 0.2676 \\
\hline & $(31.23)$ & $(27.99)$ & $(29.84)$ & $(8.77)$ & $(31.62)$ & $(14.58)$ & $(38.10)$ & $(20.83)$ & $(23.24)$ & $(38.82)$ & $(17.50)$ & $(26.86)$ \\
\hline Oct & 0.1795 & 0.1342 & 0.2419 & 0.1624 & 0.2503 & 0.1702 & 0.2817 & 0.2919 & 0.2144 & 0.6338 & 0.2368 & 0.1694 \\
\hline & $\begin{array}{l}(23.35) \\
0.0250\end{array}$ & $\begin{array}{r}(16.49) \\
-(0.001)\end{array}$ & $\begin{array}{l}(21.21) \\
0.0754)\end{array}$ & $\begin{array}{l}(7.09) \\
0.0261\end{array}$ & $\begin{array}{l}(22.71) \\
00828\end{array}$ & $\begin{array}{l}(10.60) \\
0\end{array}$ & $\begin{array}{l}(24.38) \\
0.0870\end{array}$ & $\begin{array}{l}(11.68) \\
-0.0445\end{array}$ & $\begin{array}{l}(15.67) \\
0.0705\end{array}$ & $(29.69)$ & $(13.90)$ & (17.23) \\
\hline Nov & $\begin{array}{l}0.0250 \\
(3.15)\end{array}$ & $\begin{array}{c}-0.0016 \\
(-0.17)\end{array}$ & $\begin{array}{l}0.0754 \\
(6.50)\end{array}$ & $\begin{array}{c}0.02611 \\
(1.12)\end{array}$ & $\begin{array}{l}0.0828 \\
(7.34)\end{array}$ & $\begin{array}{l}0.0238 \\
(1.45)\end{array}$ & $\begin{array}{l}0.0870 \\
(7.38)\end{array}$ & $\begin{array}{r}-0.0443 \\
(-1.74)\end{array}$ & $\begin{array}{l}0.0705 \\
(5.06)\end{array}$ & $\begin{array}{l}0.0754 \\
(3.50)\end{array}$ & $\begin{array}{l}0.1956 \\
(10.10)\end{array}$ & $\begin{array}{c}-0.0022 \\
(-0.22)\end{array}$ \\
\hline Dec & $\begin{array}{l}0.0094 \\
(1.13)\end{array}$ & $\begin{array}{l}0.0113 \\
(1.22)\end{array}$ & $\begin{array}{c}0.0558 \\
(4.75)\end{array}$ & $\begin{array}{l}-0.0407 \\
(-1.72)\end{array}$ & $\begin{array}{l}0.0597 \\
(4.87)\end{array}$ & $\begin{array}{c}-0.0443 \\
(-2.69)\end{array}$ & $\begin{array}{l}0.0898 \\
(7.53)\end{array}$ & $\begin{array}{c}-0.0510 \\
(-1.98)\end{array}$ & $\begin{array}{c}-0.0083 \\
(-0.59)\end{array}$ & $\begin{array}{l}0.0427 \\
(2.00)\end{array}$ & $\begin{array}{l}0.0433 \\
(2.42)\end{array}$ & $\begin{array}{c}-0.0032 \\
(-0.33)\end{array}$ \\
\hline$D_{t 30}$ & $\begin{array}{l}0.0332 \\
(5.34)\end{array}$ & $\begin{array}{l}0.0169 \\
(2.92\end{array}$ & $\begin{array}{r}-0.0409 \\
(-5.54)\end{array}$ & $\begin{array}{l}-0.1058 \\
(-6.54)\end{array}$ & $\begin{array}{l}0.0154 \\
(1.98)\end{array}$ & $\begin{array}{l}0.1053 \\
(9.80)\end{array}$ & $\begin{array}{r}-0.0121 \\
(-1.42)\end{array}$ & $\begin{array}{l}0.0397 \\
(2.18\end{array}$ & $\begin{array}{l}-0.1229 \\
(-1262)\end{array}$ & $\begin{array}{l}0.0680 \\
(4.72\end{array}$ & $\begin{array}{l}0.0344 \\
(2.72)\end{array}$ & $\begin{array}{r}0.0113 \\
(170))\end{array}$ \\
\hline$R^{2}$ & 0.7945 & 0.8113 & 0.8189 & 0.478 & 0.8178 & 0.4918 & 0.8473 & 0.7469 & 0.7071 & 0.87 & 0.5359 & 0.7833 \\
\hline Adj. $R^{2}$ & 0.7928 & 0.8092 & 0.8169 & 0.4722 & 0.8157 & 0.4862 & 0.8457 & 0.7441 & 0.7038 & 0.8686 & 0.5308 & 0.7809 \\
\hline No. of Obs & 1,462 & 1,097 & 1,099 & 1,096 & 1,099 & 1,088 & 1,097 & 1,097 & 1,097 & 1,097 & 1,097 & 1,097 \\
\hline Prob $>$ F & 0.0000 & 0.0000 & $\begin{array}{l}0.0000 \\
0.0737\end{array}$ & 0.0000 & $\begin{array}{l}0.0000 \\
0.0739\end{array}$ & 0.0000 & 0.0000 & 0.0000 & 0.0000 & 0.0000 & 0.0000 & 0.0000 \\
\hline Root MSE & 0.0595 & 0.0546 & 0.0737 & 0.1534 & 0.0739 & 0.1073 & 0.0775 & 0.1675 & 0.0917 & 0.1431 & 0.1196 & 0.0661 \\
\hline
\end{tabular}

Note: T-statistics are presented in parentheses. $D_{t 30}$ represents the change in the dependent variable in the 30 days after the terrorist attack. 
Table 5: The effects of terrorist attacks for each city on the total number of seats sold

\begin{tabular}{|c|c|c|c|c|c|c|c|c|c|c|c|c|}
\hline & $\begin{array}{c}\text { Frankfurt } \\
2011\end{array}$ & $\begin{array}{l}\text { Paris } \\
2013 \\
\end{array}$ & $\begin{array}{c}\text { Paris } \\
\text { Jan 2015 } \\
\end{array}$ & $\begin{array}{l}\text { Copenh. } \\
2015\end{array}$ & $\begin{array}{l}\text { Paris } \\
\text { Nov 2015 } \\
\end{array}$ & $\begin{array}{c}\text { Berlin } \\
2016\end{array}$ & $\begin{array}{c}\text { Turkey } \\
2016\end{array}$ & $\begin{array}{l}\text { Nice } \\
2016\end{array}$ & $\begin{array}{c}\text { Brussels } \\
2016 \\
\end{array}$ & $\begin{array}{l}\text { Manch. } \\
2017\end{array}$ & $\begin{array}{l}\text { Stockh. } \\
2017\end{array}$ & $\begin{array}{l}\text { London } \\
2017\end{array}$ \\
\hline Constant & 1.1174 & 1.1573 & 1.1494 & 1.0573 & 1.1487 & 1.0822 & 1.1818 & 0.9661 & 1.0601 & 1.0250 & 1.0712 & 1.2005 \\
\hline Japuary & $(18.14)$ & (15.55) & (13.71) & $\begin{array}{l}(4.92) \\
0.448\end{array}$ & $(14.66)$ & $(6.79)$ & $\begin{array}{l}(16.93) \\
(16.908\end{array}$ & $(6.13)$ & $(7.82)$ & $\begin{array}{l}(0.77) \\
0.070\end{array}$ & $\begin{array}{l}(4.41) \\
0\end{array}$ & (13.61) \\
\hline January & $\begin{array}{l}-0.0878 \\
(-10.90)\end{array}$ & $\begin{array}{c}-0.0484 \\
(-5.08)\end{array}$ & $\begin{array}{c}-0.0315 \\
(-2.96)\end{array}$ & $\begin{array}{c}-0.1448 \\
(-4.98)\end{array}$ & $\begin{array}{c}-0.0284 \\
(-2.69)\end{array}$ & $\begin{array}{l}-0.1138 \\
(-4.95)\end{array}$ & $\begin{array}{l}0.0282 \\
(3.00)\end{array}$ & $\begin{array}{l}-0.1441 \\
(-6.79)\end{array}$ & $\begin{array}{r}-0.0713 \\
(-3.89)\end{array}$ & $\begin{array}{c}-0.0722 \\
(-3.92)\end{array}$ & $\begin{array}{c}-0.1418 \\
(-4.20)\end{array}$ & $\begin{array}{l}-0.0502 \\
(-4.09)\end{array}$ \\
\hline February & - & - & - & - & - & - & - & - & - & - & - & - \\
\hline March & 0.0288 & 0.0355 & 0.0496 & 0.1136 & 0.0565 & 0.0476 & 0.0592 & 0.2053 & 0.0429 & 0.0758 & 0.0602 & 0.0465 \\
\hline & (3.14) & (3.43) & $(4.40)$ & $(3.56)$ & $(5.19)$ & $(2.15)$ & $(6.10)$ & $(9.36)$ & $(2.28)$ & $(4.11)$ & $(1.78)$ & (3.74) \\
\hline April & $\begin{array}{l}0.0941 \\
(10.91)\end{array}$ & $\begin{array}{l}0.0860 \\
(8.25)\end{array}$ & $\begin{array}{l}0.1490 \\
(13.10)\end{array}$ & $\begin{array}{l}0.1572 \\
(5.22)\end{array}$ & $\begin{array}{l}0.1559 \\
(14.20)\end{array}$ & $\begin{array}{l}0.1088 \\
(4.89)\end{array}$ & $\begin{array}{l}0.1796 \\
(18.35)\end{array}$ & $\begin{array}{l}0.3909 \\
(17.68)\end{array}$ & $\begin{array}{l}0.1758 \\
(8.47)\end{array}$ & $\begin{array}{l}0.2299 \\
(12.37)\end{array}$ & $\begin{array}{l}0.1459 \\
\end{array}$ & 0.1257 \\
\hline May & $\begin{array}{l}(10.91) \\
0.1458\end{array}$ & $\begin{array}{l}(8.25) \\
0.1043\end{array}$ & $\begin{array}{l}(13.10) \\
0.1930\end{array}$ & $\begin{array}{l}(5.22) \\
0.1901\end{array}$ & $\begin{array}{l}(14.20) \\
0.1999\end{array}$ & $\begin{array}{l}(4.89) \\
0.1551\end{array}$ & $\begin{array}{l}(18.35) \\
0.2365\end{array}$ & $\begin{array}{l}(17.68) \\
0.4542\end{array}$ & $\begin{array}{l}(8.47) \\
0.1951\end{array}$ & $\begin{array}{l}(12.37) \\
0.3884\end{array}$ & $\begin{array}{l}(4.28) \\
0.2067\end{array}$ & $\begin{array}{l}(9.79) \\
0.1851\end{array}$ \\
\hline & $(17.02)$ & (10.13) & (17.10) & $(6.36)$ & $\begin{array}{l}(18.35) \\
(18.99\end{array}$ & $\begin{array}{l}.1501 \\
(7.32)\end{array}$ & $\begin{array}{l}0.2405 \\
(24.37)\end{array}$ & $\begin{array}{l}0.4542 \\
(20.70)\end{array}$ & $\begin{array}{l}0.1931 \\
(10.34)\end{array}$ & $\begin{array}{l}0.3884 \\
(20.80)\end{array}$ & $(5.69)$ & $\begin{array}{l}0.1851 \\
(15.09)\end{array}$ \\
\hline June & 0.1692 & 0.1370 & 0.2389 & 0.2363 & 0.2458 & 0.1472 & 0.3017 & 0.5121 & 0.2304 & $\begin{array}{l}20.8015 \\
0.4815\end{array}$ & 0.2429 & $\begin{array}{l}(15.09) \\
0.2173\end{array}$ \\
\hline July & $(19.60)$ & (13.13) & $(21.01)$ & $(7.84)$ & $(22.38)$ & $(6.24)$ & $(30.83)$ & $(23.14)$ & $(12.13)$ & $(24.93)$ & $(7.14)$ & (17.58) \\
\hline July & $\begin{array}{l}0.1486 \\
(17.21\end{array}$ & $\begin{array}{l}0.1087 \\
(10.43\end{array}$ & 0.2145 & $\begin{array}{l}0.1437 \\
(4.45)\end{array}$ & 0.2214 & 0.0867 & 0.3697 & 0.5225 & 0.2407 & 0.5196 & 0.1781 & 0.2243 \\
\hline August & $\begin{array}{l}(17.21) \\
0.1501\end{array}$ & $\begin{array}{l}(10.43) \\
0.0882\end{array}$ & $\begin{array}{l}(19.05) \\
0.1739\end{array}$ & $\begin{array}{l}(4.45) \\
0.1441\end{array}$ & $\begin{array}{l}(20.377) \\
0.1808\end{array}$ & $\begin{array}{l}3.904 \\
0.0647\end{array}$ & $\begin{array}{r}(34.17) \\
0.3584\end{array}$ & $\begin{array}{l}(21.55) \\
0.4781\end{array}$ & $\begin{array}{l}(12.67) \\
0.2221\end{array}$ & $(27.96)$ & $\begin{array}{l}(5.23) \\
0.0827\end{array}$ & (18.14) \\
\hline & $(17.65)$ & $(8.59)$ & $\begin{array}{l}(15.51) \\
(15.09\end{array}$ & $\begin{array}{l}(5.09) \\
(1441\end{array}$ & $\begin{array}{l}(16.72) \\
(160)\end{array}$ & $(2.95)$ & $\begin{array}{l}0.304 \\
(37.20)\end{array}$ & $\begin{array}{l}0.41 .96) \\
(21.96)\end{array}$ & $\begin{array}{l}0.2211 \\
(11.87)\end{array}$ & $\begin{array}{l}0.5402 \\
(29.52)\end{array}$ & $\begin{array}{l}0.0827 \\
(2.47)\end{array}$ & $\begin{array}{l}0.2329 \\
(19.13)\end{array}$ \\
\hline September & 0.1470 & 0.1288 & 0.2043 & 0.1713 & 0.2112 & 0.1595 & 0.3193 & 0.4443 & 0.2418 & 0.5095 & 0.2365 & 0.2148 \\
\hline & $(17.06)$ & $(12.34)$ & (17.97) & (5.68) & $(19.23)$ & $(7.16)$ & $(32.63)$ & $(20.09)$ & $(12.80)$ & $(27.41)$ & $(6.95)$ & (17.33) \\
\hline October & 0.1104 & 0.0675 & 0.1454 & 0.1480 & 0.1523 & 0.1206 & 0.1877 & 0.2504 & 0.1613 & 0.3420 & 0.2152 & 0.1282 \\
\hline & $(12.89)$ & $(6.52)$ & $(12.88)$ & $(4.95)$ & $(13.98)$ & $(5.46)$ & $(19.34)$ & $(11.42)$ & $(8.56)$ & $(18.55)$ & $(6.68)$ & (10.45) \\
\hline November & $\begin{array}{l}0.0247 \\
(2.79)\end{array}$ & $\begin{array}{l}0.0038 \\
(0.33)\end{array}$ & $\begin{array}{l}0.0426 \\
(3.71)\end{array}$ & $\begin{array}{l}0.0513 \\
(1.68)\end{array}$ & $\begin{array}{l}0.0484 \\
(4.34)\end{array}$ & $\begin{array}{l}-0.0138 \\
(-0.61)\end{array}$ & $\begin{array}{l}0.0808 \\
(8.17)\end{array}$ & $\begin{array}{c}-0.0354 \\
(-1.58)\end{array}$ & $\begin{array}{l}0.0585 \\
(3.04)\end{array}$ & $\begin{array}{c}-0.0237 \\
(-1.27)\end{array}$ & $\begin{array}{l}0.1754 \\
(4.79)\end{array}$ & $\begin{array}{l}-0.0285 \\
(-2.30)\end{array}$ \\
\hline December & $\begin{array}{r}-0.0149 \\
(-1.60)\end{array}$ & $\begin{array}{l}-0.0068 \\
(-0.58)\end{array}$ & $\begin{array}{l}0.0131 \\
(1.13)\end{array}$ & $\begin{array}{l}-0.0389 \\
(-1.26)\end{array}$ & $\begin{array}{l}0.0152 \\
(1.25)\end{array}$ & $\begin{array}{l}-0.0888 \\
(-391)\end{array}$ & 0.0788 & $\begin{array}{l}-0.0396 \\
(-1.75)\end{array}$ & -0.0255 & $\begin{array}{l}-0.0526 \\
(-285)\end{array}$ & 0.0646 & $\begin{array}{l}-0.0439 \\
(-359)\end{array}$ \\
\hline$D_{t 30}$ & 0.0387 & -0.0027 & -0.0334 & -0.1007 & 0.0164 & 0.0635 & -0.0238 & -0.0068 & -0.0892 & 0.0619 & -0.0259 & 0.0162 \\
\hline & & $(-0.36)$ & $(-4.56)$ & $-4.78)$ & $(2.14)$ & $(4.30)$ & $(-3.34)$ & $(0.44)$ & $(-6.66)$ & $(4.98)$ & $(-1.08)$ & (1.96) \\
\hline$R^{2}$ & 0.6143 & 0.4323 & 0.6223 & 0.2302 & 0.6209 & 0.2560 & 0.7944 & 0.7292 & 0.436 & 0.7893 & 0.1915 & 0.6382 \\
\hline Adj. $R^{2}$ & 0.6111 & 0.4260 & 0.6181 & 0.2217 & 0.6167 & 0.2477 & 0.7921 & 0.7262 & 0.4297 & 0.787 & 0.1825 & 0.6342 \\
\hline $\begin{array}{l}\text { Number of Obs } \\
\text { Prob }>\text { F }\end{array}$ & $\begin{array}{c}1,462 \\
0.0000\end{array}$ & $\begin{array}{l}1,097 \\
0.0000\end{array}$ & $\begin{array}{l}1,099 \\
0.0000\end{array}$ & $\begin{array}{l}1,096 \\
0.0000\end{array}$ & $\begin{array}{c}1,099 \\
0.0000\end{array}$ & $\begin{array}{l}1,088 \\
0.0000\end{array}$ & $\begin{array}{l}1,097 \\
0.0000\end{array}$ & $\begin{array}{l}1,097 \\
0,0000\end{array}$ & $\begin{array}{l}1,097 \\
0.0000\end{array}$ & $\begin{array}{l}1,097 \\
0.0000\end{array}$ & $\begin{array}{l}1,097 \\
0.0000\end{array}$ & $\begin{array}{l}1,097 \\
0.0000\end{array}$ \\
\hline Root MSE & & 0.0694 & 0.0729 & 0.2002 & 0.0731 & 0.1478 & 0.0651 & 0.1471 & 0.1264 & 0.1236 & 0.2264 & 0.0823 \\
\hline
\end{tabular}

Note: T-statistics are presented in parentheses. $D_{t 30}$ represents the change in the dependent variable in the 30 days after the terrorist attack. 
Table 6: Estimated change in ASKs and seats sold during 30-day period after terrorist attack

\begin{tabular}{|c|c|c|c|c|c|c|c|c|c|c|c|c|}
\hline & $\begin{array}{c}\text { Frankfurt } \\
2011\end{array}$ & $\begin{array}{l}\text { Paris } \\
2013\end{array}$ & $\begin{array}{c}\text { Paris } \\
\text { Jan } 2015 \\
\end{array}$ & $\begin{array}{c}\text { Copenh. } \\
2015\end{array}$ & $\begin{array}{c}\text { Paris } \\
\text { Nov } 2015 \\
\end{array}$ & $\begin{array}{c}\text { Berlin } \\
2016\end{array}$ & $\begin{array}{c}\text { Turkey } \\
2016\end{array}$ & $\begin{array}{l}\text { Nice } \\
2016 \\
\end{array}$ & $\begin{array}{c}\text { Brussels } \\
2016\end{array}$ & $\begin{array}{l}\text { Manch. } \\
2017\end{array}$ & $\begin{array}{c}\text { Stockh. } \\
2017\end{array}$ & $\begin{array}{c}\text { Londor } \\
2017\end{array}$ \\
\hline \multicolumn{13}{|c|}{ Panel A: 30-day Response to Terrorism Attacks in European Union originating fights } \\
\hline ASKS & $\begin{array}{l}0.0468 \\
(6.52)\end{array}$ & $\begin{array}{c}-0.0023 \\
(-0.34)\end{array}$ & $\begin{array}{c}-0.0253 \\
(-3.56)\end{array}$ & $\begin{array}{c}-0.1160 \\
(-6.72)\end{array}$ & $\begin{array}{c}-0.0059 \\
(-0.80)\end{array}$ & $\begin{array}{l}0.0761 \\
(7.62)\end{array}$ & $\begin{array}{l}-0.0527 \\
(-5.54)\end{array}$ & $\begin{array}{c}-0.3162 \\
(-8.40)\end{array}$ & $\begin{array}{l}-0.1184 \\
(-9.48)\end{array}$ & $\begin{array}{l}0.0806 \\
(5.30)\end{array}$ & $\begin{array}{l}0.0414 \\
(3.24)\end{array}$ & $\begin{array}{l}0.0248 \\
(2.52)\end{array}$ \\
\hline Seats & $\begin{array}{l}0.0411 \\
(5.14)\end{array}$ & $\begin{array}{c}-0.0073 \\
(-0.86)\end{array}$ & $\begin{array}{c}-0.0304 \\
(-3.84)\end{array}$ & $\begin{array}{c}-0.1013 \\
(-4.64)\end{array}$ & $\begin{array}{c}-0.0158 \\
(-1.88)\end{array}$ & $\begin{array}{l}0.0590 \\
(3.96)\end{array}$ & $\begin{array}{c}-0.0288 \\
(-3.96)\end{array}$ & $\begin{array}{c}-0.3245 \\
(-8.36)\end{array}$ & $\begin{array}{c}-0.0869 \\
(-6.00)\end{array}$ & $\begin{array}{l}0.0647 \\
(4.96)\end{array}$ & $\begin{array}{c}-0.0264 \\
(-1.08)\end{array}$ & $\begin{array}{l}0.0199 \\
(1.96)\end{array}$ \\
\hline \multicolumn{13}{|c|}{ Panel B: 30-day Response to Terrorism Attacks in United States originating flights } \\
\hline ASKS & $\begin{array}{l}0.0258 \\
(3.28)\end{array}$ & $\begin{array}{l}0.0416 \\
(4.02)\end{array}$ & $\begin{array}{l}-0.0582 \\
(-5.74)\end{array}$ & $\begin{array}{c}-0.0619 \\
(-2.30)\end{array}$ & $\begin{array}{l}-0.0234 \\
(-2.20)\end{array}$ & $\begin{array}{l}0.4865 \\
(9.32)\end{array}$ & $\begin{array}{l}-0.2041 \\
(-14.28)\end{array}$ & $\begin{array}{l}0.0100 \\
(0.50)\end{array}$ & $\begin{array}{l}-0.1377 \\
(-5.84)\end{array}$ & $\begin{array}{l}0.0381 \\
(7.68)\end{array}$ & $\begin{array}{c}-0.0025 \\
(-0.10)\end{array}$ & $\begin{array}{c}0.0017 \\
(0.26\end{array}$ \\
\hline Seats & $\begin{array}{l}0.0298 \\
(3.84)\end{array}$ & $\begin{array}{l}0.0407 \\
(4.04)\end{array}$ & $\begin{array}{l}-0.0567 \\
(-5.72)\end{array}$ & $\begin{array}{c}-0.0645 \\
(-2.48)\end{array}$ & $\begin{array}{c}-0.0176 \\
(-1.68)\end{array}$ & $\begin{array}{l}0.4482 \\
(9.08)\end{array}$ & $\begin{array}{l}-0.1928 \\
(-13.80)\end{array}$ & $\begin{array}{c}-0.0017 \\
(-0.10)\end{array}$ & $\begin{array}{c}-0.1291 \\
(-5.66)\end{array}$ & $\begin{array}{l}0.0351 \\
(3.70)\end{array}$ & $\begin{array}{c}-0.0071 \\
(-0.32)\end{array}$ & $\begin{array}{l}0.0018 \\
(0.28)\end{array}$ \\
\hline
\end{tabular}

Note: T-statistics are presented in parentheses. $D_{t 30}$ represents the change in the dependent variable in the 30 days after the terrorist attack. 
Table 7: The effects of terrorist attacks on business seats sold

\begin{tabular}{|c|c|c|c|c|c|c|c|}
\hline & $\begin{array}{c}\text { Frankfurt } \\
2011\end{array}$ & $\begin{array}{l}\text { Paris } \\
2013 \\
\end{array}$ & $\begin{array}{c}\text { Paris } \\
\text { Jan } 2015\end{array}$ & $\begin{array}{c}\text { Paris } \\
\text { Nov 2015 }\end{array}$ & $\begin{array}{l}\text { Manch. } \\
2017\end{array}$ & $\begin{array}{l}\text { Stockh. } \\
2017\end{array}$ & $\begin{array}{c}\text { London } \\
2017\end{array}$ \\
\hline Constant & $\begin{array}{c}0.8188^{* * *} \\
(53.36)\end{array}$ & $\begin{array}{c}1.1573^{* * *} \\
(15.53)\end{array}$ & $\begin{array}{c}0.9051 * * * \\
(19.99)\end{array}$ & $\begin{array}{c}0.8941 * * * \\
(21.41)\end{array}$ & $\begin{array}{c}0.6933^{* * *} \\
(4.71)\end{array}$ & $\begin{array}{c}0.8001 * * * \\
(31.57)\end{array}$ & $\begin{array}{c}0.9351 * * * \\
(14.38)\end{array}$ \\
\hline January & $\begin{array}{c}-0.0692^{* * *} \\
(-3.47)\end{array}$ & $\begin{array}{c}-0.0484^{* * *} \\
(-5.08)\end{array}$ & $\begin{array}{c}-0.0005 \\
(-0.01)\end{array}$ & $\begin{array}{l}0.0490 \\
(0.87)\end{array}$ & $\begin{array}{c}-0.0169 \\
(-0.83)\end{array}$ & $\begin{array}{c}-0.1052^{* * *} \\
(-2.99)\end{array}$ & $\begin{array}{c}-0.025 * * * \\
(-2.80)\end{array}$ \\
\hline February & - & - & - & - & - & - & - \\
\hline March & $\begin{array}{c}0.1625^{* * *} \\
(7.09)\end{array}$ & $\begin{array}{c}0.0355^{* * * *} \\
(3.43)\end{array}$ & $\begin{array}{c}-0.0767 \\
(-1.26)\end{array}$ & $\begin{array}{c}0.0339 \\
(0.58)\end{array}$ & $\begin{array}{c}-0.0094 \\
(-0.46)\end{array}$ & $\begin{array}{c}0.0597 * \\
(1.69)\end{array}$ & $\begin{array}{c}0.0321 * * * \\
(3.45)\end{array}$ \\
\hline April & $\begin{array}{c}0.1911^{* * *} \\
(8.88)\end{array}$ & $\begin{array}{l}0.0861^{* * *} \\
(8.25)\end{array}$ & $\begin{array}{l}0.0215 \\
(0.35)\end{array}$ & $\begin{array}{c}0.1321^{* *} \\
(2.26)\end{array}$ & $\begin{array}{c}0.1834^{* * *} \\
(8.89)\end{array}$ & $\begin{array}{c}0.1060^{* * *} \\
(2.98)\end{array}$ & $\begin{array}{c}0.1082^{* * * *} \\
(11.23)\end{array}$ \\
\hline May & $\begin{array}{c}0.2464^{* * *} \\
(11.54)\end{array}$ & $\begin{array}{c}0.1044^{* * * *} \\
(10.13)\end{array}$ & $\begin{array}{c}0.2888^{* * *} \\
(4.74)\end{array}$ & $\begin{array}{c}0.3995^{* * * *} \\
(6.88)\end{array}$ & $\begin{array}{c}0.1605 * * * \\
(7.74)\end{array}$ & $\begin{array}{c}0.1781 * * * \\
(4.70)\end{array}$ & $\begin{array}{c}0.1321 * * * \\
(14.36)\end{array}$ \\
\hline June & $\begin{array}{c}0.2765^{* * *} \\
(12.85)\end{array}$ & $\begin{array}{c}0.1370^{* * * *} \\
(13.13)\end{array}$ & $\begin{array}{c}0.3325^{* * *} \\
(5.41)\end{array}$ & $\begin{array}{c}0.4432^{* * * *} \\
(7.57)\end{array}$ & $\begin{array}{c}0.2023 * * * \\
(9.43)\end{array}$ & $\begin{array}{c}0.1940^{* * *} \\
(5.46)\end{array}$ & $\begin{array}{c}0.1539^{* * *} * \\
(16.60)\end{array}$ \\
\hline July & $\begin{array}{c}0.2370^{* * *} \\
(11.02)\end{array}$ & $\begin{array}{c}0.1087^{* * *} \\
(10.43)\end{array}$ & $\begin{array}{l}0.1670^{* * *} \\
(2.75)\end{array}$ & $\begin{array}{c}0.2777^{* * *} \\
(4.79)\end{array}$ & $\begin{array}{c}0.1804 * * * \\
(8.74)\end{array}$ & $\begin{array}{c}0.1002 * * * \\
(2.82)\end{array}$ & $\begin{array}{c}0.1427 * * * \\
(15.39)\end{array}$ \\
\hline August & $\begin{array}{c}0.2771^{* * *} \\
(13.08)\end{array}$ & $\begin{array}{c}0.0882^{* * * *} \\
(8.59)\end{array}$ & $\begin{array}{l}0.0924 \\
(1.53)\end{array}$ & $\begin{array}{c}0.2031^{* * * *} \\
(3.52)\end{array}$ & $\begin{array}{c}0.1651 * * * \\
(8.13)\end{array}$ & $\begin{array}{c}-0.0389 \\
(-1.11)\end{array}$ & $\begin{array}{c}0.1265^{* * *} * \\
(13.86)\end{array}$ \\
\hline September & $\begin{array}{c}0.1505^{* * *} \\
(7.01)\end{array}$ & $\begin{array}{c}0.1288^{* * *} \\
(12.34)\end{array}$ & $\begin{array}{l}0.1051 \\
(1.71)\end{array}$ & $\begin{array}{c}0.2158^{* * * *} \\
(3.69)\end{array}$ & $\begin{array}{c}0.1748^{* * *} \\
(8.47)\end{array}$ & $\begin{array}{c}0.1360 * * * \\
(3.83)\end{array}$ & $\begin{array}{c}0.1216^{* * *} \\
(13.08)\end{array}$ \\
\hline October & $\begin{array}{c}0.1010^{* * *} \\
(4.73)\end{array}$ & $\begin{array}{c}0.0675^{* * *} * \\
(6.52)\end{array}$ & $\begin{array}{l}0.0717 \\
(1.18)\end{array}$ & $\begin{array}{c}0.1823^{* * *} \\
(3.14)\end{array}$ & $\begin{array}{c}0.1176 * * * \\
(5.74)\end{array}$ & $\begin{array}{c}0.1499^{* * *} * \\
(4.46)\end{array}$ & $\begin{array}{c}0.0804 * * * \\
(8.75)\end{array}$ \\
\hline November & $\begin{array}{c}-0.0062 \\
(-0.28)\end{array}$ & $\begin{array}{l}0.0039 \\
(0.33)\end{array}$ & $\begin{array}{c}-0.0506 \\
(-0.81)\end{array}$ & $\begin{array}{l}0.0115 \\
(0.19)\end{array}$ & $\begin{array}{l}0.0069 \\
(0.34)\end{array}$ & $\begin{array}{c}0.1598^{* * *} \\
(4.18)\end{array}$ & $\begin{array}{c}-0.0145^{*} \\
(-1.57)\end{array}$ \\
\hline December & $\begin{array}{c}-0.0312 \\
(-1.35)\end{array}$ & $\begin{array}{c}-0.0068 \\
(-0.58)\end{array}$ & $\begin{array}{c}-0.0408 \\
(-0.65)\end{array}$ & $\begin{array}{c}-0.1337^{* *} \\
(-2.07)\end{array}$ & $\begin{array}{c}0.0416^{* *} \\
(2.04)\end{array}$ & $\begin{array}{c}0.0620^{*} \\
(1.76)\end{array}$ & $\begin{array}{c}-0.0322 * * * \\
(-3.51)\end{array}$ \\
\hline$D_{t 30}$ & $\begin{array}{c}-0.1541 \\
(-8.90)\end{array}$ & $\begin{array}{c}-0.0026 \\
(-0.36)\end{array}$ & $\begin{array}{l}-0.5347 \\
(-13.56)\end{array}$ & $\begin{array}{l}-0.6951 \\
(-16.96)\end{array}$ & $\begin{array}{c}-0.0061 \\
(-0.44)\end{array}$ & $\begin{array}{c}-0.0484 \\
(-1.94)\end{array}$ & $\begin{array}{c}-0.0460 \\
(-7.42)\end{array}$ \\
\hline$R^{2}$ & 0.3618 & 0.4323 & 0.1421 & 0.1613 & 0.2765 & 0.1221 & 0.5582 \\
\hline $\begin{array}{l}\text { Adj. } R^{2} \\
\text { Number of Obs } \\
\text { Prob }>\text { F }\end{array}$ & $\begin{array}{c}0.3565 \\
1,462 \\
0.0000\end{array}$ & $\begin{array}{c}0.4260 \\
1,097 \\
0.0000\end{array}$ & $\begin{array}{c}0.1326 \\
1,099 \\
0.0000\end{array}$ & $\begin{array}{c}0.152 \\
1,099 \\
0.0000\end{array}$ & $\begin{array}{c}0.2685 \\
1,097 \\
0.0000\end{array}$ & $\begin{array}{c}0.1124 \\
1,097 \\
0.0000\end{array}$ & $\begin{array}{c}0.5533 \\
1,097 \\
0.0000\end{array}$ \\
\hline Root MSE & 0.1652 & 0.0694 & 0.3938 & 0.3894 & 0.1373 & 0.2363 & 0.0616 \\
\hline
\end{tabular}

Note: T-statistics are presented in parentheses while $* * *, * *$ and $*$ denote the significance of the GARCH(1,1) estimates at the $1 \%, 5 \%$ and $10 \%$ levels respectively. 
Table 8: The effects of terrorist attacks on economy seats sold

\begin{tabular}{|c|c|c|c|c|c|c|c|}
\hline & $\begin{array}{c}\text { Frankfurt } \\
2011 \\
\end{array}$ & $\begin{array}{l}\text { Paris } \\
2013 \\
\end{array}$ & $\begin{array}{c}\text { Paris } \\
\text { Jan } 2015 \\
\end{array}$ & $\begin{array}{c}\text { Paris } \\
\text { Nov } 2015 \\
\end{array}$ & $\begin{array}{c}\text { Manch. } \\
2017 \\
\end{array}$ & $\begin{array}{c}\text { Stockh. } \\
2017 \\
\end{array}$ & $\begin{array}{c}\text { London } \\
2017 \\
\end{array}$ \\
\hline Constant & $\begin{array}{c}1.1117^{* * *} \\
(18.08)\end{array}$ & $\begin{array}{c}1.1516^{* * *} \\
(9.79)\end{array}$ & $\begin{array}{c}1.1392 * * * \\
(13.52)\end{array}$ & $\begin{array}{c}1.1395 * * * \\
(14.59)\end{array}$ & $\begin{array}{l}1.021 \\
(0.74)\end{array}$ & $\begin{array}{c}1.0641^{* * *} \\
(4.36)\end{array}$ & $\begin{array}{c}1.1926 * * * \\
(12.91)\end{array}$ \\
\hline January & $\begin{array}{c}-0.0886^{* * *} \\
(-11.00)\end{array}$ & $\begin{array}{c}-0.0519^{* * *} \\
(-3.44)\end{array}$ & $\begin{array}{c}-0.0357^{* * * *} \\
(-3.34)\end{array}$ & $\begin{array}{c}-0.0368^{* * *} \\
(-3.48)\end{array}$ & $\begin{array}{c}-0.0744^{* * *} \\
(-3.89)\end{array}$ & $\begin{array}{c}-0.1447^{* * *} \\
\quad(-4.27)\end{array}$ & $\begin{array}{c}-0.0523^{* * *} * \\
(-4.07)\end{array}$ \\
\hline February & - & - & - & - & - & - & - \\
\hline March & $\begin{array}{c}0.0204^{* *} \\
(2.22)\end{array}$ & $\begin{array}{c}0.0365^{* *} \\
(2.23)\end{array}$ & $\begin{array}{c}0.0616^{* * *} \\
(5.43)\end{array}$ & $\begin{array}{c}0.0592^{* * *} \\
(5.45)\end{array}$ & $\begin{array}{c}0.0790 * * * \\
(4.13)\end{array}$ & $\begin{array}{c}0.0601 * \\
(1.77)\end{array}$ & $\begin{array}{c}0.0477^{* * *} \\
(3.67)\end{array}$ \\
\hline April & $\begin{array}{c}0.0870^{* * *} \\
(10.10)\end{array}$ & $\begin{array}{c}0.0899^{* * *} \\
(5.44)\end{array}$ & $\begin{array}{c}0.1612^{* * *} \\
(14.10)\end{array}$ & $\begin{array}{c}0.1587^{* * *} \\
(14.49)\end{array}$ & $\begin{array}{c}0.2324 * * * \\
(12.05)\end{array}$ & $\begin{array}{c}0.1491 * * * \\
(4.36)\end{array}$ & $\begin{array}{c}0.1277^{* * *} \\
(9.49)\end{array}$ \\
\hline May & $\begin{array}{c}0.1389^{* * *} \\
(16.24)\end{array}$ & $\begin{array}{c}0.0388 * * \\
(2.38)\end{array}$ & $\begin{array}{c}0.1847^{* * *} \\
(16.28)\end{array}$ & $\begin{array}{c}0.1822 * * * \\
(16.77)\end{array}$ & $\begin{array}{c}0.3969^{* * * *} \\
(20.49)\end{array}$ & $\begin{array}{c}0.2092 * * * \\
(5.74)\end{array}$ & $\begin{array}{c}0.1902 * * * \\
(14.80)\end{array}$ \\
\hline June & $\begin{array}{c}0.1620^{* * * *} \\
(18.80)\end{array}$ & $\begin{array}{c}0.0681 * * * \\
(4.13)\end{array}$ & $\begin{array}{c}0.2307 * * * \\
(20.18)\end{array}$ & $\begin{array}{c}0.2282 * * * \\
(20.83)\end{array}$ & $\begin{array}{c}0.4914^{* * *} \\
(24.52)\end{array}$ & $\begin{array}{c}0.2474^{* * *} \\
\quad(7.24)\end{array}$ & $\begin{array}{c}0.2235^{* * *} * \\
(17.25)\end{array}$ \\
\hline July & $\begin{array}{c}0.1425^{* * *} \\
(16.54)\end{array}$ & $\begin{array}{c}0.1290^{* * *} \\
\quad(7.82)\end{array}$ & $\begin{array}{c}0.2221 * * * \\
(19.63)\end{array}$ & $\begin{array}{c}0.2197^{* * *} \\
(20.27)\end{array}$ & $\begin{array}{c}0.5313^{* * *} \\
(27.55)\end{array}$ & $\begin{array}{c}0.1839^{* * *} \\
\quad(5.38)\end{array}$ & $\begin{array}{c}0.2316^{* * *} \\
(17.88)\end{array}$ \\
\hline August & $\begin{array}{c}0.1420^{* * *} \\
(16.73)\end{array}$ & $\begin{array}{c}0.0631 * * * \\
(3.89)\end{array}$ & $\begin{array}{c}0.1849 * * * \\
(16.42)\end{array}$ & $\begin{array}{c}0.1825 * * * \\
(16.92)\end{array}$ & $\begin{array}{c}0.5528^{* * * *} \\
(29.12)\end{array}$ & $\begin{array}{c}0.0911 * * * \\
(2.71)\end{array}$ & $\begin{array}{c}0.2421 * * * \\
(18.98)\end{array}$ \\
\hline September & $\begin{array}{c}0.1462 * * * \\
(17.00)\end{array}$ & $\begin{array}{c}0.0669^{* * *} \\
(4.06)\end{array}$ & $\begin{array}{c}0.2156 * * * \\
(18.86)\end{array}$ & $\begin{array}{c}0.2131 * * * \\
(19.46)\end{array}$ & $\begin{array}{c}0.5209^{* * * *} \\
(27.01)\end{array}$ & $\begin{array}{c}0.2437^{* * *} \\
\quad(7.13)\end{array}$ & $\begin{array}{c}0.2229^{* * *} * \\
(17.15)\end{array}$ \\
\hline October & $\begin{array}{c}0.1107^{* * *} \\
(12.95)\end{array}$ & $\begin{array}{l}0.0064 \\
(0.39)\end{array}$ & $\begin{array}{c}0.1545^{* * *} \\
(13.62)\end{array}$ & $\begin{array}{c}0.1521 * * * \\
(13.99)\end{array}$ & $\begin{array}{c}0.3503^{* * *} \\
(18.31)\end{array}$ & $\begin{array}{c}0.2188^{* * *} \\
\quad(6.76)\end{array}$ & $\begin{array}{c}0.1321^{* * *} \\
(10.28)\end{array}$ \\
\hline November & $\begin{array}{c}0.0268 \\
(3.03)^{* * *}\end{array}$ & $\begin{array}{c}-0.0949^{* * *} * \\
(-5.11)\end{array}$ & $\begin{array}{c}0.0518^{* * *} \\
(4.49)\end{array}$ & $\begin{array}{c}0.0533^{* * *} \\
(4.79)\end{array}$ & $\begin{array}{c}-0.0243 \\
(-1.26)\end{array}$ & $\begin{array}{c}0.1756^{* * *} \\
\quad(4.77)\end{array}$ & $\begin{array}{c}-0.0298^{* *} \\
(-2.30)\end{array}$ \\
\hline December & $\begin{array}{c}-0.0139 \\
(-1.50)\end{array}$ & $\begin{array}{c}-0.0711 * * * \\
(-3.83)\end{array}$ & $\begin{array}{l}0.0181 \\
(1.56)\end{array}$ & $\begin{array}{c}0.0320 * * * \\
(2.66)\end{array}$ & $\begin{array}{c}-0.0572 * * * \\
(-2.99)\end{array}$ & $\begin{array}{c}0.0644^{*} \\
(1.90)\end{array}$ & $\begin{array}{c}-0.0458 * * * \\
(-3.56)\end{array}$ \\
\hline$D_{t 30}$ & $\begin{array}{l}0.0485 * * * \\
\quad(7.00)\end{array}$ & $\begin{array}{l}0.0903^{* * *} \\
(7.72)\end{array}$ & $\begin{array}{c}0.0117 \\
(1.40)\end{array}$ & $\begin{array}{c}-0.0558^{* * *} \\
(-7.28)\end{array}$ & $\begin{array}{c}0.0636^{* * *} \\
(4.92)\end{array}$ & $\begin{array}{c}-0.0227 \\
(-0.96)\end{array}$ & $\begin{array}{c}0.0201 * * \\
(2.32)\end{array}$ \\
\hline$R^{2}$ & 0.6034 & 0.2356 & 0.6129 & 0.6174 & 0.7849 & 0.1966 & 0.6323 \\
\hline Adj. $R^{2}$ & 0.6001 & 0.2272 & 0.6087 & 0.6131 & 0.7825 & 0.1877 & 0.6283 \\
\hline Number of Obs & 1,462 & 1,097 & 1,099 & 1,099 & 1,097 & 1,097 & 1,097 \\
\hline Prob $>F$ & 0.0000 & 0.0000 & 0.0000 & 0.0000 & 0.0000 & 0.0000 & 0.0000 \\
\hline Root MSE & 0.0662 & 0.1098 & 0.0733 & 0.0729 & 0.1283 & 0.2273 & 0.0862 \\
\hline
\end{tabular}

Note: T-statistics are presented in parentheses while $* * *, * *$ and $*$ denote the significance of the GARCH(1,1) estimates at the $1 \%, 5 \%$ and $10 \%$ levels respectively.

Table 9: Change in Business and Economy class passenger numbers post-attack

\begin{tabular}{|c|c|c|c|c|c|c|c|}
\hline & $\begin{array}{l}\text { Frankfurt } \\
2011 \\
\end{array}$ & $\begin{array}{l}\text { Paris } \\
2013 \\
\end{array}$ & $\begin{array}{c}\text { Paris } \\
\text { Jan } 2015 \\
\end{array}$ & $\begin{array}{c}\text { Paris } \\
\text { Nov } 2015 \\
\end{array}$ & $\begin{array}{l}\text { Manchester } \\
2017 \\
\end{array}$ & $\begin{array}{l}\text { Stockholm } \\
2017 \\
\end{array}$ & $\begin{array}{l}\text { London } \\
2017 \\
\end{array}$ \\
\hline \multicolumn{8}{|c|}{ Panel A: 30-day Business Class Response to Terrorism Attacks } \\
\hline $\mathrm{EU}$ & $\begin{array}{c}-0.3082^{* * *} \\
(-9.54)\end{array}$ & $\begin{array}{c}-0.0073 \\
(-0.86)\end{array}$ & $\begin{array}{c}-0.6457^{* * *} * \\
(-13.40)\end{array}$ & $\begin{array}{c}-0.8328 * * * \\
(-16.72)\end{array}$ & $\begin{array}{c}-0.0343^{* *} \\
(-2.04)\end{array}$ & $\begin{array}{c}-0.0467^{*} \\
(-1.80)\end{array}$ & $\begin{array}{c}-0.0805^{* * *} * \\
(-8.16)\end{array}$ \\
\hline US & $\begin{array}{c}0.0549 * * * \\
(6.98)\end{array}$ & $\begin{array}{c}0.0922^{* * *} \\
(7.20)\end{array}$ & $\begin{array}{c}0.0192^{* *} \\
(2.34)\end{array}$ & $\begin{array}{c}-0.0645^{* * *} \\
(-7.52)\end{array}$ & $\begin{array}{c}0.0674^{* * *} \\
(4.98)\end{array}$ & $\begin{array}{c}-0.0231 \\
(-0.94)\end{array}$ & $\begin{array}{c}0.0236^{* *} \\
(2.26)\end{array}$ \\
\hline \multicolumn{8}{|c|}{ Panel B: 30-day Economy Seats Response to Terrorism Attacks } \\
\hline EU & $\begin{array}{c}0.0278^{* * *} \\
(3.06)\end{array}$ & $\begin{array}{c}0.0407^{* * *} * \\
(4.04)\end{array}$ & $\begin{array}{c}-0.0662^{* * *} \\
(-7.56)\end{array}$ & $\begin{array}{c}0.0424^{* * *} \\
(4.60)\end{array}$ & $\begin{array}{c}0.2140 \\
(8.86)\end{array}$ & $\begin{array}{c}-0.0152 \\
(-0.72)\end{array}$ & $\begin{array}{c}-0.0030 \\
(-0.44)\end{array}$ \\
\hline US & $\begin{array}{c}0.0123 \\
(1.58)\end{array}$ & $\begin{array}{c}0.0618^{* * *} \\
(5.86)\end{array}$ & $\begin{array}{c}-0.0540 * * * \\
(-5.32)\end{array}$ & $\begin{array}{c}0.0114 \\
(1.06)\end{array}$ & $\begin{array}{c}0.0257 \\
(1.22)\end{array}$ & $\begin{array}{c}-0.0059 \\
(-0.26)\end{array}$ & $\begin{array}{c}0.0040 \\
(0.62)\end{array}$ \\
\hline
\end{tabular}

Note: The above table presents the estimated 30-day response of business and economy class passengers after each terrorist attack. For brevity, only the associated dummy variable is included. Please contact the authors for a full list of regression results. Only terrorist attacks with complete data are included in this analysis. EU represents the total number of passengers that have departed from a European airport en route to the attacked city. US represents United States sourced passengers. T-statistics are presented in parentheses while $* * *, * *$ and $*$ denote the significance of the GARCH( 1,1$)$ estimates at the $1 \%, 5 \%$ and $10 \%$ levels respectively. 
Table 10: ARMA-GARCH-calculated seasonally-adjusted one-month revenue and ticket price response to European terrorist attacks

\begin{tabular}{|c|c|c|c|c|c|c|c|c|c|}
\hline City & MeanCon & L1 & $\mathrm{L} 2$ & VarCon & $\mathrm{AR}(12)$ & DUMMY & $\mathrm{ARCH}$ & GARCH & Revenue \\
\hline Paris 2015 & $\begin{array}{c}0.1354^{* * *} \\
(4.46)\end{array}$ & $\begin{array}{c}-0.2835 * * * \\
(-2.71)\end{array}$ & $\begin{array}{c}-0.1289^{* *} \\
(-2.22)\end{array}$ & $\begin{array}{c}0.0225^{* *} \\
(2.13)\end{array}$ & $\begin{array}{c}0.7547^{* * *} \\
\quad(8.02)\end{array}$ & $\begin{array}{c}4.4629^{* * *} \\
(3.65)\end{array}$ & $\begin{array}{c}0.2016^{* *} \\
(2.53)\end{array}$ & $\begin{array}{c}0.784^{* * *} \\
(5.11)\end{array}$ & $-0.1011 * * *$ \\
\hline Copenhagen 2015 & $\begin{array}{c}0.1802 * * * \\
(3.49)\end{array}$ & $\begin{array}{c}-0.0643 \\
(-1.07)\end{array}$ & $\begin{array}{c}0.1239 \\
(1.36)\end{array}$ & $\begin{array}{c}0.2394 * * * \\
(12.65)\end{array}$ & $\begin{array}{c}0.0214 * * * \\
(3.05)\end{array}$ & $\begin{array}{c}-1.9313^{* *} \\
(-2.29)\end{array}$ & $\begin{array}{c}0.2408^{* * *} \\
(3.36)\end{array}$ & $\begin{array}{c}0.7311^{* * * *} \\
\quad(4.52)\end{array}$ & $0.1793^{* * *}$ \\
\hline Paris 2015 (Nov) & $\begin{array}{c}0.1244^{* * *} \\
(3.46)\end{array}$ & $\begin{array}{l}0.2091 \\
(1.14)\end{array}$ & $\begin{array}{l}0.1953 \\
(1.21)\end{array}$ & $\begin{array}{c}0.0210^{* * *} \\
(13.24)\end{array}$ & $\begin{array}{c}0.8225^{* * *} \\
(19.13)\end{array}$ & $\begin{array}{c}0.6879^{* * *} \\
(4.10)\end{array}$ & $\begin{array}{c}0.2954^{*} \\
(1.79)\end{array}$ & $\begin{array}{c}0.674^{* * *} \\
(7.24)\end{array}$ & $-0.2234 * * *$ \\
\hline Berlin 2016 & $\begin{array}{c}0.2383 \\
(0.69)\end{array}$ & $\begin{array}{c}0.1171^{* *} \\
(2.56)\end{array}$ & - & $\begin{array}{c}0.2384^{* * *} \\
(5.13)\end{array}$ & $\begin{array}{c}-0.8329^{* *} \\
(-2.56)\end{array}$ & $\begin{array}{c}0.6369^{* * *} \\
(3.29)\end{array}$ & $\begin{array}{c}0.0843^{* * *} \\
(4.24)\end{array}$ & $\begin{array}{c}0.8942^{* * *} \\
(5.82)\end{array}$ & $-0.0167^{* * *}$ \\
\hline Turkey 2016 & $\begin{array}{c}0.0096^{* * * *} \\
(2.98)\end{array}$ & $\begin{array}{c}0.1542^{* * *} \\
(2.60)\end{array}$ & $\begin{array}{c}0.1969^{*} \\
(1.83)\end{array}$ & $\begin{array}{c}0.02469^{* * *} \\
(4.62)\end{array}$ & $\begin{array}{c}0.6195^{* * *} \\
(7.76)\end{array}$ & $\begin{array}{c}3.0655^{* * *} \\
(3.65)\end{array}$ & $\begin{array}{c}0.0682^{* * *} \\
(2.99)\end{array}$ & $\begin{array}{c}0.9257^{* * * *} \\
(3.53)\end{array}$ & $-0.4677^{* * *}$ \\
\hline Nice 2016 & $\begin{array}{l}0.1657 \\
(0.25)\end{array}$ & $\begin{array}{c}-0.0087 \\
(-1.00)\end{array}$ & - & $\begin{array}{c}0.2369^{* * *} \\
(11.31)\end{array}$ & $\begin{array}{c}1.0067^{* *} \\
(10.25)\end{array}$ & $\begin{array}{c}6.4816^{* * *} \\
(4.88)\end{array}$ & $\begin{array}{c}0.3651^{* * *} \\
(3.79)\end{array}$ & $\begin{array}{c}0.6191 * * * \\
(3.21)\end{array}$ & $-0.0162^{* * *}$ \\
\hline Brussels 2016 & $\begin{array}{c}0.2923^{* * * *} \\
(3.18)\end{array}$ & $\begin{array}{c}0.0953 \\
(0.55)\end{array}$ & $\begin{array}{c}0.2235^{* *} \\
(2.39)\end{array}$ & $\begin{array}{c}0.3064^{* * *} \\
(35.01)\end{array}$ & $\begin{array}{c}0.8149^{* * *} \\
(9.94)\end{array}$ & $\begin{array}{c}2.5228^{*} \\
(1.67)\end{array}$ & $\begin{array}{c}0.4725^{* * *} \\
(3.63)\end{array}$ & $\begin{array}{c}0.4991 * * * \\
(3.01)\end{array}$ & $-0.1666^{* * *}$ \\
\hline Manchester 2017 & $\begin{array}{l}0.2691 \\
(1.53)\end{array}$ & $\begin{array}{c}-0.3696^{*} \\
(-1.91)\end{array}$ & $\begin{array}{c}0.5312^{* * *} \\
(2.79)\end{array}$ & $\begin{array}{c}0.2367^{* * *} \\
(6.01)\end{array}$ & $\begin{array}{c}0.7404^{* * *} \\
\quad(6.57)\end{array}$ & $\begin{array}{c}4.609^{* *} \\
(2.16)\end{array}$ & $\begin{array}{c}0.3121^{* * *} \\
(2.98)\end{array}$ & $\begin{array}{c}0.6022^{* * *} \\
(2.94)\end{array}$ & $-0.1460 * * *$ \\
\hline Stockholm 2017 & $\begin{array}{c}0.1462 \\
(0.72)\end{array}$ & $\begin{array}{c}0.0114 \\
(1.06)\end{array}$ & - & $\begin{array}{c}0.2278^{* * *} \\
(2.92)\end{array}$ & $\begin{array}{l}0.1292 \\
(0.53)\end{array}$ & $\begin{array}{l}0.466 \\
(1.15)\end{array}$ & $\begin{array}{c}0.3382^{* *} \\
(2.35)\end{array}$ & $\begin{array}{c}0.6024^{*} \\
(1.84)\end{array}$ & $-0.0506^{* * *}$ \\
\hline London 2017 & $\begin{array}{c}0.0942^{* * *} \\
(2.88)\end{array}$ & $\begin{array}{c}-0.1350^{*} \\
(-1.89)\end{array}$ & $\begin{array}{c}-0.1299 \\
(-1.28)\end{array}$ & $\begin{array}{c}0.4052^{* * *} \\
\quad(6.77)\end{array}$ & $\begin{array}{c}0.3201^{* *} \\
(2.00)\end{array}$ & $\begin{array}{c}2.531^{* * * *} \\
(3.82)\end{array}$ & $\begin{array}{c}0.4258^{* * *} \\
(2.90)\end{array}$ & $\begin{array}{c}0.5509^{* * *} \\
(3.14)\end{array}$ & $-0.0059 * * *$ \\
\hline
\end{tabular}

Note: The above table represents the dummy variable coefficients for the individual ARMA-GARCH regressions analysing the effects of European terrorist attacks on revenue and ticket prices in the month immediately afterwards. The nature of the methodology results in the variables being adjusted for seasonality. T-statistics are presented in parentheses while $* * *, * *$ and $*$ denote the significance of the $\operatorname{GARCH}(1,1)$ estimates at the $1 \%, 5 \%$ and $10 \%$ levels respectively. 
Table 11: ARMA-GARCH-calculated seasonally-adjusted one-month revenue and ticket price response to European terrorist attacks based on flight origin

\begin{tabular}{|c|c|c|c|c|c|c|}
\hline \multicolumn{7}{|c|}{ Flights arriving from Europe } \\
\hline & \multicolumn{2}{|c|}{ Business Class } & \multicolumn{2}{|c|}{ Premium Coach } & \multicolumn{2}{|c|}{ Discount Coach } \\
\hline City & Revenue & Ticket Price & Revenue & Ticket Price & Revenue & Ticket Price \\
\hline Paris 2015 & 0.0001 & $-0.0656^{* * *}$ & $-0.6849^{* * *}$ & $-0.1417^{* * *}$ & $-0.2546^{* * *}$ & $0.0023^{* * *}$ \\
\hline Copenhagen 2015 & $0.0210^{* *}$ & $-0.0317^{* * *} *$ & $0.3165^{*}$ & $0.0956^{* * *}$ & $0.0804^{* * *}$ & -0.0098 \\
\hline Paris 2015 & $-0.2689 * *$ & $-0.0544^{* * *}$ & $-0.1425^{* * *}$ & $-0.0455^{* * *}$ & $-0.0068^{* * *}$ & $-0.0459^{* * *}$ \\
\hline Berlin 2016 & 0.0032 & $-0.0738^{* * *}$ & $-0.4393^{* *}$ & $0.1573^{* * *}$ & $0.0982^{* * *}$ & $0.2063^{*}$ \\
\hline Turkey 2016 & $-0.3934^{* * *}$ & 0.0396 & $-0.8326^{*}$ & -0.3158 & $-0.2979 * * *$ & $-0.1256^{* *}$ \\
\hline Nice 2016 & $-0.0170^{* *}$ & $0.1074 * * *$ & $-0.4504^{* * *}$ & $-0.1696^{* * *}$ & $-0.0377 * * *$ & $-0.0813^{* * *}$ \\
\hline Brussels 2016 & $-0.0713^{* * *}$ & $0.2205^{* * *}$ & $-0.2126^{* * *}$ & $-0.0564 * * *$ & $-0.0807 * * *$ & $-0.0735 * * *$ \\
\hline Manchester 2017 & $-0.6064^{* *}$ & $-0.5459^{* *}$ & $-0.0748^{* * *}$ & $-0.1866^{* * *}$ & $-0.0816^{* * *}$ & $-0.0416 * * *$ \\
\hline Stockholm 2017 & $0.2869^{* * *}$ & $-0.0647 * * *$ & $-0.5015^{* *}$ & $-0.1802^{* * *}$ & $0.0222^{* * *}$ & $-0.0996 * * *$ \\
\hline London 2017 & $0.0191^{* * *}$ & $-0.0652^{* * *}$ & $-0.0869^{* * *}$ & $-0.2489^{*}$ & $-0.0692^{* * *}$ & $-0.1426 * * *$ \\
\hline
\end{tabular}

\begin{tabular}{|c|c|c|c|c|c|c|}
\hline \multicolumn{7}{|c|}{ Flights arriving from the United States } \\
\hline & \multicolumn{2}{|c|}{ Business Class } & \multicolumn{2}{|c|}{ Premium Coach } & \multicolumn{2}{|c|}{ Discount Coach } \\
\hline City & Revenue & Ticket Price & Revenue & Ticket Price & Revenue & Ticket Price \\
\hline Paris 2015 & $-0.2226 * * *$ & $0.0455^{* * *}$ & $0.1566^{* * *}$ & $0.2056^{* * *}$ & $-0.0119^{* * *}$ & $0.1189^{* * *}$ \\
\hline Copenhagen 2015 & $0.0206 * * *$ & $0.0090 * * *$ & 0.3151 & 0.3132 & $0.1213^{* * *}$ & $-0.0795^{*}$ \\
\hline Paris 2015 & $-0.0157 * * *$ & $-0.0071^{* * *}$ & $0.1422^{* * *}$ & $-0.0306^{* * *}$ & $0.0203^{* * *}$ & $-0.0729 * * *$ \\
\hline Berlin 2016 & $0.0864^{* * *}$ & $-0.0286^{* * *}$ & 0.2696 & $0.0671^{* * *}$ & $0.0201^{* * *}$ & $-0.0230 * * *$ \\
\hline Turkey 2016 & $-0.4091^{* * *}$ & $-0.1238^{* * *}$ & $-0.5734^{* * *}$ & $-0.3184^{* * *}$ & $-0.3318^{*}$ & $-0.0924^{* * *}$ \\
\hline Nice 2016 & $-0.0525^{* * *}$ & $-0.0515^{* * *}$ & $-0.0366^{* * *}$ & $-0.1626^{* * *}$ & $-0.1228 * * *$ & $-0.1728^{*}$ \\
\hline Brussels 2016 & $-0.0649 * * *$ & $0.0197 * * *$ & $-0.2183^{* * *}$ & $-0.0763^{* * *}$ & $-0.0957 * * *$ & $-0.0625 * * *$ \\
\hline Manchester 2017 & -0.5469 & $-0.6826^{*}$ & $-0.3128 * * *$ & $-0.0722^{* * *}$ & $-0.3586^{*}$ & $-0.1642 * * *$ \\
\hline Stockholm 2017 & $-0.0589 * * *$ & $-0.1574 * * *$ & $-0.0717^{* * *}$ & $0.0123 * * *$ & $-0.1643^{* * *}$ & $-0.0867 * * *$ \\
\hline London 2017 & $0.2437 * * *$ & $-0.0217^{* * *}$ & $0.1647^{* * *}$ & $-0.0827 * * *$ & $-0.0736 * * *$ & $-0.0864 * * *$ \\
\hline
\end{tabular}

Note: The table represents the dummy variable coefficients for the individual ARMA-GARCH calculated regressions analysing the effects of European terrorist attacks on revenue and ticket prices in the month immediately afterwards. The nature of the methodology results in the variables being adjusted for seasonality. For brevity, only the results based on the revenue and ticket price variables are included. Further coefficients are available from the authors on request. T-statistics are presented in parentheses while $* * *, * *$ and $*$ denote the significance of the $\operatorname{GARCH}(1,1)$ estimates at the $1 \%$, $5 \%$ and $10 \%$ levels respectively. 